PONTIFÍCIA UNIVERSIDADE CATÓLICA DO RIO DE JANEIRO

\title{
Motivações das consumidoras da Geração Y e as estratégias de comunicação das marcas para cabelos cacheados e crespos
}

Adriana Barbosa Farias

Trabalho de Conclusão de Curso

Centro de Ciências sociais - CCS

DePARTAMENTO de AdMINISTRAÇÃo

Graduação em Administração de Empresas 
Adriana Barbosa Farias

Motivações das consumidoras da Geração Y e as estratégias de comunicação das marcas para cabelos cacheados e crespos

Trabalho de Conclusão de Curso

Trabalho de Conclusão de Curso, apresentado ao programa de graduação em Administração da PUC-Rio como requisito parcial para a obtenção do titulo de graduação em Administração.

Orientador(a): Vivian Peuker Sardon Steinhäuser

Rio de Janeiro, junho de 2021. 


\section{Agradecimentos}

Gostaria de agradecer a minha orientadora, que me auxiliou e guiou durante esse processo.

Às entrevistadas que disponibilizaram de seu tempo para participar da pesquisa.

A todos os funcionários da PUC.

Agradecer aos professores da PUC e da escola que são fontes de inspiração.

Agradecer a minha família, minha filha, Lívia, minha mãe, Joana, meu pai, Sabino e minha irmã, Sabrina, que sempre me apoiaram.

Muito obrigada a todos. 


\section{Resumo}

Farias, Adriana. Motivações das consumidoras da Geração Y e estratégias de comunicação das marcas para cabelos cacheados e crespos. Rio de Janeiro, 2021. 57 p. Trabalho de Conclusão de Curso - Departamento de Administração. Pontifícia Universidade Católica do Rio de Janeiro.

Farias, Adriana. O seguinte trabalho visa abranger as tendências de comunicação das marcas que são atrativas e importantes para o público feminino cacheado e crespo, especificamente as cariocas da Geração Y, bem como entender suas motivações de compra e uso de produtos capilares. Para compreender o comportamento do consumidor, foi realizada uma pesquisa qualitativa de natureza exploratória, que objetivou encontrar diferentes pontos de vista das entrevistadas.

Estudos de mercado mostram a importância dessa categoria de produtos para brasileiras que buscam a valorização dos cabelos naturais. E a poderosa indústria cosmética precisa se reinventar para atender essa demanda crescente dos últimos anos.

Palavras- chave

Comunicação, motivação, cabelo, crespo, cacheado, natural 


\section{Abstract}

Farias, Adriana. Motivations of Generation $Y$ consumers and theBrand communication strategies for curly and afrohair hair. Rio de Janeiro, 2021. p 57. Trabalho de Conclusão de Curso - Departamento de Administração. Pontifícia Universidade Católica do Rio de Janeiro.

This study aims to cover the communication trends of brands that are attractive and important to curly and afrohair female audiences, specifically those from Rio de Janeiro from Generation Y, as well as understanding their motivations for buying and using hair care products. To understand consumer behavior, an exploratory qualitative research was carried out, which aimed to find different points of view of the interviewees.

Several researches show how relevant is this category of products for Brazilian women seeking to enhance their natural hair. And the powerful cosmetic industry needs to reinvent itself to meet this growing demand of recent Years.

\section{Key-words}

Communication, motivations, curly, afrohair, natural hair 


\section{Sumário}

1 O tema e o problema de estudo 1

1.1. Objetivo Final 3

1.2. Objetivos Intermediários do Estudo 3

1.3. Delimitação e Foco do Estudo 3

1.4. Justificativa relevância do estudo 4

2 Mercado cosmético 6

3 Referencial teórico 8

3.1. Cabelos e marcas na história 8

$\begin{array}{ll}\text { 3.2. Marcas para cacheadas e crespas } & 10\end{array}$

3.3. Comunicação das marcas 12

3.3.1. Estratégia de fonte 13

3.3.2. Estratégia de mensagem 16

3.3.3. Meios de Comunicação 20

3.4. Motivações das consumidoras 22

3.5. O processo de compra 26

4 Métodos e procedimentos de coleta e de análise de dados do estudo 30 4.1. Etapas da coleta de dados 30

4.2. Fontes de informação selecionas para a coleta de dados no estudo 31

4.3. Procedimentos e instrumentos de coleta de dados utilizados no estudo

4.4. Formas de tratamento e análise dos dados coletados para o estudo32

4.5. Limitações do Estudo

5 Apresentação e análise dos resultados 34

5.1. Perfil das entrevistadas 34

5.2. Resultado das entrevistas 35

5.2.1. Motivações das consumidoras e comportamento de compra 36 
5.2.2. Marcas nas Mídias Sociais 40

5.2.3. Endosso das Influenciadoras Digitais 42

5.2.4. Sustentabilidade e Diversidade na Mensagem 43

5.2.5. Sugestões das Consumidoras 45

6 Conclusões e recomendações para novos estudos 47

6.1. Recomendações para no os estudos 49

6.2. Sugestões 49

7 Referências Bibliográficas $\quad 51$

$\begin{array}{ll}\text { Anexo } 1 & 56\end{array}$

\section{Lista de figuras}

Figura 1: Manifesto da marca Soul Power ................................................... 17

Figura 2: Campanha sobre diversidade com influenciadoras da SEDA ............. 17

Figura 3: Gráfico consumo de produtos sustentáveis ................................... 18

Figura 4: Selos Cruelty Free e Vegano..................................................... 19

Figura 5: Estatísticas do YouTube em relação às cacheadas e crespas ............ 22

Figura 6: Pirâmide de Maslow ....................................................................... 24

Figura 7: Envolvimento $=\mathrm{f}$ (pessoa, situação e objeto) ................................... 25

Figura 8: Processo de decisão de compra .................................................. 27

\section{Lista de Tabelas}

Tabela 1: Perfil dos entrevistados Erro! Indicador não definido. 


\section{0 tema e o problema de estudo}

Desde a Antiguidade, há evidências arqueológicas do uso de cosméticos para higiene pessoal e embelezamento, datando de 4.000 anos antes de Cristo. A cosmética é difundida há décadas no Brasil, majoritariamente entre as mulheres, e os produtos que compõem esse segmento são constituídos por subsistências sintéticas ou naturais para pele, unhas, lábios e cabelo. (GALEMBECK; CSORDAS, [2009?])

$\mathrm{Na}$ indústria cosmética, o valor intangível transmitido aos produtos é muito expressivo, com isso, uma cliente não compra um creme ou condicionador, por exemplo, visando somente seus atributos (físicos), porém, conjuntamente a isso, espera-se ter a percepção do que ele representa como símbolo de beleza ou de aceitação, além de descobrir quais sensações e sentimentos positivos que 0 produto pode despertar com si própria e com quem está ao seu redor. A comunicação é a responsável pela formação da imagem da marca na mente do consumidor, ela gera percepções, sentimentos e transmite uma identidade de marca, o intuito desse processo é buscar uma diferenciação perante o público alvo. (VASQUEZ, 2006)

Braga (2018) reflete sobre os fatores que influenciam às estratégias de comunicação no que tange aos movimentos sociais e midiáticos na contemporaneidade. Assim, a autora aborda pautas identitárias em seu estudo, afirmando que aspectos como etnia e raça, gênero, idade e inquietações ecológicas geram novas formas de identificação.

Nesse cenário, a mulher brasileira é reconhecida por sua pluralidade de cabelos, o que é consequência da diversidade étnica da população. Esse público também tem como característica a abertura às mudanças, no que se refere aos cuidados capilares; além do que, aspectos como poder, saúde, sensualidade e jovialidade estão intrinsicamente ligados ao que considera ser uma imagem de "cabelo bonito". (DINO, 2019) O cabelo também é um meio da mulher expressar seu estilo, de fornecer indícios da sua personalidade, sendo considerado um dos caminhos para o desenvolvimento da autoconfiança feminina.

O cabelo feminino é uma forma de expressão tanto cultural quanto pessoal, e no decorrer da história mundial, as tendências de cor, corte e curvatura dos fios 
foi seguido à risca por milhares de mulheres. No Brasil, nos últimos anos, houve o "boom" no que diz respeito à aceitação dos fios naturais cacheados e crespos, esse acontecimento foi um divisor de águas no mercado de cosméticos, porquanto foi colocado em xeque a pressão estética do "padrão cabelo liso" enraizado coletivamente nos diferentes segmentos da sociedade. (OLIVEIRA, 2019)

De acordo com Sacchitiello (2018), até pouco tempo, a publicidade de produtos para cabelos no país era predominantemente voltada para as mulheres de cabelos lisos, não havendo representatividade para os outros tipos de fios, mas de acordo com uma pesquisa da agência Heads, essa realidade está mudando, e a aceitação dos cabelos naturais começa a influenciar no tipo de conteúdo das propagandas nos diferentes meios de comunicação.

O Dossiê BrandLab: A Revolução dos Cachos de 2017, relatório promovido pelo Google Brandlab, revelou que de 2016 para 2017, a busca por cabelos cacheados cresceu $232 \%$ e, no mesmo período, a procura no Google por este tipo capilar superou, pela primeira vez no país, a procura por cabelos lisos. (GOOGLE,2017) Além disso, o interesse pelos cabelos afro cresceu 309\%, e na mesma pesquisa foi constatado que apenas $18 \%$ das brasileiras nascem com os fios naturalmente lisos. (ABIHPEC, 2018)

Já têm alguns anos que os comportamentos e as motivações das mulheres cacheadas e crespas são assuntos em voga na sociedade. Agora elas são vistas pelas empresas como consumidoras em potencial de um lucrativo nicho dentro do segmento de cosmético capilar, consequentemente, houve o acirramento da concorrência e um posicionamento da indústria em relação à comunicação com esse público em específico. (PINHEIRO,2018)

Ainda segundo o Dossiê BrandLab: A Revolução dos Cachos (2017), 1 em cada 3 mulheres diz já ter sofrido preconceito por conta da tipologia capilar, e 4 em cada 10 mulheres já sentiram vergonha por ser cacheada ou crespa (GOOGLE,2017). O que reflete que apesar de todos avanços e transformações, ainda há um caminho árduo a ser percorrido.

Levando em consideração os fatores motivacionais e os estímulos para uma decisão de consumo, o presente estudo levanta o seguinte questionamento: Quais são as motivações das consumidoras da Geração $\mathrm{Y}$, e as principais estratégias de comunicação das marcas para cabelos cacheados e crespos? 


\subsection{Objetivo Final}

Considerando o processo de compra das consumidoras, o presente trabalho tem como objetivo analisar a estratégia de comunicação de produtos para cabelos cacheados e crespos e entender a motivação da consumidora da Geração Y.

\subsection{Objetivos Intermediários do Estudo}

Para que o objetivo principal seja alcançado, é necessário ter como base os objetivos intermediários.

$>$ Analisar quais estratégias de comunicação das marcas mais influenciam as consumidoras a comprar.

$>$ Identificar o comportamento de compra das consumidoras de produtos para cabelos cacheados e crespos.

> Estudar quais as principais motivações de compra e uso dos produtos para cabelos cacheados e crespos.

\subsection{Delimitação e Foco do Estudo}

Dentre todas as gerações, os Ys ou Millenials, são os que mais vivenciaram aceleradas mudanças tecnológicas. O seu comportamento foi moldado devido às constantes inovações, tais como: internet, smartphones, tablets e computadores. (CAETANO,2015) Os Ys representaram uma verdadeira revolução no mercado de trabalho; possuem grande poder de informação por serem hábeis em influenciar sua rede de relacionamentos e são consideradas pessoas mais impacientes.

As mulheres dessa geração são superconectadas, possuem um estilo de vida mais saudável e entendem que os cuidados pessoais têm muito mais a ver com a saúde e bem-estar do que com a vaidade, elas têm o poder de influenciar e informar as mulheres de outras gerações. (ABIHPEC, 2018) 
Buscou-se conhecer especificamente as Millennials, pois a autora desta pesquisa faz parte dessa geração, possuindo com isso a curiosidade de saber as motivações e comportamentos desse público em relação às marcas e produtos para cuidados capilares. Conforme Lipkin e Perrymore (2010), os pertencentes à Geração Y são os nascidos entre os anos de 1980 e o ano de 2000.

Serão analisadas mulheres de diferentes tons de pele, de todas as classes sociais e com cabelos de formatos e texturas diferentes mesmo entre as cacheadas e crespas.

O mercado cosmético capilar é muito extenso e diverso, por isso a abordagem da entrevista consiste em mencionar produtos especializados numa tipologia de cabelo que, no caso, são os voltados para as cacheadas e crespas.

Com o intuito de unificar os propósitos estabelecidos neste trabalho, tornouse necessário estabelecer algumas delimitações. Este estudo vai atender os seguintes aspectos:

1. Temporal: Primeiro semestre de 2021.

2. Objeto de estudo: público consumidor de cosméticos capilares, comunicação, motivação.

3. Geográfico: Rio de Janeiro.

4. Mulheres da Geração Y: de 21 a 34 anos.

\subsection{Justificativa da relevância do estudo}

O presente trabalho é importante, pois estuda um assunto que está em destaque na sociedade. As consumidoras deste estudo são peças chave, não somente pelo aspecto comercial, mas porque suas ideias, visões, atitudes e comportamentos têm papel inspirador em sua rede de convivência. Então, compreender suas motivações pode contribuir para que outras mulheres decidam assumir os fios naturais.

Além disso, o trabalho também pode ser relevante para pesquisas futuras no meio acadêmico, uma vez que ainda é um tema recente e, com isso, não há muitos trabalhos publicados. Por fim, para consultas de diferentes segmentos de empresas que estão inseridas no processo produtivo; pequenas e médias organizações podem beneficiar-se com a identificação de aspectos comportamentais e motivacionais das clientes, fazendo com que se tenha a reformulação do planejamento estratégico e/ou novas ações de marketing. 


\section{Mercado cosmético}

Este capítulo destina-se a apresentar dados e informações sobre a indústria cosmética, bem como tendências relevantes para que sirvam de base para 0 estudo.

Segundo Almeida (2020), o mercado cosmético permanece em crescimento apesar da crise no país, uma vez que o setor apresentou vendas crescentes na ordem de 5,1\% em 2020, conforme informações do simulador da ABIHIPEC (Associação Brasileira de Higiene Pessoal, Perfumaria e Cosméticos). Ademais, pode ser considerada uma taxa excelente, dado que o PIB no período teve uma projeção realizada pelo Banco Central de 2,3\%, e de 2,10\% considerando a indústria em geral.

O autor Weber (2020), relata que o mercado de beleza e cuidados pessoais no Brasil e no mundo tem sido agitado pelo movimento das gigantes, como Natura e Avon, todavia as pequenas marcas se mobilizam para atender nichos por meio digital, estabelecendo, assim, um diálogo mais próximo com seu público. Ele ainda traz dados do relatório ABIHPEC e informa que cinco empresas concentram $47,8 \%$ do mercado brasileiro - Natura\&Co, Boticário, Unilever, grupo L'Oréal e Colgate Palmolive Co. Entretanto, o número de empresas do setor HPPC registrado na Anvisa em 2018 era de 2.794, isso é o reflexo da maciça participação das pequenas organizações nesse mercado, no qual muitas delas são focadas em atender públicos de nicho.

Já a Euromonitor International, apresentou que de 2013 a 2018 houve crescimento de $24,5 \%$ no valor das vendas de varejo em reais. (WEBER, 2020) A organização também prevê as seguintes tendências no mercado de beleza e cuidados pessoais para os próximos cinco anos: engajamento digital, posicionamentos éticos e produtos com atributos orgânicos e naturais. Em 2019, - Brasil ocupava a quarta posição no ranking global no setor de HPPC, respondendo por cerca de 6,9\% do mercado mundial, atrás apenas dos EUA, CHINA e Japão, e movimentando US $\$ 29,62$ bilhões em consumo no mercado nacional do setor, segundo dados da Euromonitor de 2019. (NEGÓCIOSSC, 2021) 
Os consumidores preocupados com o seu bem-estar e também com o meio ambiente visam um novo tipo de relação com os produtos desse segmento. À vista disso, a ascensão do mercado cosmético sustentável é uma realidade, já que é a terceira maior preocupação dos consumidores brasileiros; $32 \%$ das pessoas levam em conta fatores "verdes" na composição dos produtos e das embalagens na tomada de decisão de compra; além disso, 18,2\% do faturamento de higiene e beleza vem de lares com atitudes e hábitos saudáveis, dados que foram disponibilizados por um estudo da Nielsen. (MERCADO\&CONSUMO, 2019)

Antes vistos como supérfluos, itens como shampoos e condicionadores ganharam importância nas prateleiras das lojas e, na atualidade, são considerados como essenciais para manutenção da saúde e higiene. Conforme o painel de dados do mercado da ABIHPEC, cosméticos capilares tiveram destaque em 2020, pois se comparado a 2019, shampoos obtiveram um crescimento de vendas (ex-factory) de 7,9\%, já condicionadores de 18,6\% e, por fim, produtos de tratamento capilar de 12,6\%. (BRAZIL BEAUTY NEWS, 2021)

De acordo com um estudo da Kantar Worldpanel realizado em 2018, as mulheres são as maiores consumidoras de produtos para cabelos, já os homens preferem itens da perfumaria; e, no país, o mercado capilar movimentou $R \$ 8$ bilhões, ainda no mesmo relatório é salientado que de 2017 para 2018 houve um crescimento de $4,5 \%$ no consumo da cesta de shampoo, pós shampoo e tintura. (MORAES, 2018) 


\section{Referencial teórico}

Neste capítulo são apresentados e discutidos aspectos conceituais e estudos relacionados ao tema de estudo em investigação que servirão de base para a análise realizada.

Esta seção está dividida em quatro partes e abordam, respectivamente, a questão do cabelo e marcas na história e suas implicações na atualidade. Nas próximas seções são discutidas as marcas para cacheadas e crespas, comunicação das marcas, motivações e processo de decisão de compra, que são questões importantes para compreender a consumidora foco da pesquisa.

\subsection{Cabelos e marcas na história}

Em diferentes épocas os cabelos carregam em si uma multiplicidade de significados. Desde o Antigo Egito, passando por povos mulçumanos, judaicos e cristãos nota-se que há uma enorme relevância do cabelo no que diz respeito às dinâmicas sociais em diferentes sociedades.

Os egípcios tinham como costume usar perucas, adornos e apliques, o que já naquela época movimentava um comércio de cabelo humano. Eles eram muito ligados às práticas estéticas que até hoje ainda vigoram na sociedade: como cortes, tranças, tingimento e raspagem; e, gostavam de ostentar seus cabelos e penteados, de cuidá-los. Além disso, os fios capilares eram também considerados objeto de desejo entre homens e mulheres. Alguns povos já interpretavam o cabelo feminino como símbolo de sedução, representando uma tentação para os homens e que, então, deveria ser escondido. Esse tipo de pensamento era comum para povos de teologia judaica, muçulmana e cristã. (QUINTÃO,2013)

Em contrapartida, durante os séculos XVII e XVIII na Europa, o cabelo virou sinônimo de status e luxo, isso foi consequência da intensificação do capitalismo e da disseminação da moda entre os nobres. Nesse cenário, a aparência das mulheres era considerada um reflexo do poder de seus maridos; e a ornamentação capilar virou uma febre que envolvia o uso de adereços chamativos, dentre eles, pérolas, flores, conchas, plumas e fitas. Elas também 
eram auxiliadas por seus estilistas capilares e suas mucamas para ajudá-las a esculpir seus enormes penteados. As mulheres europeias, que eram adeptas da ornamentação capilar, precisavam ter os cabelos lisos e longos para realizar tal prática. (QUINTÃO,2013)

Durante muitos séculos, o cabelo crespo foi considerado inferior ao liso, reflexo do racismo e preconceito enraizados na sociedade, como ratifica a autora a seguir:

\begin{abstract}
...desde pelo menos o século XIX, o cabelo liso do branco europeu vem sendo associado a características positivas - ao cabelo "bom" - enquanto o cabelo crespo do negro vem sendo associado a características negativas - ao cabelo "ruim" - categorizando crespos como inferiores a lisos. (QUINTÃO,2013, p.17)
\end{abstract}

Dessa maneira, milhares de pessoas com essa estrutura de cabelo buscavam métodos de alisamento capilar como forma de se adaptar ao padrão liso europeu, até mesmo como meio de conseguir superar obstáculos sociais. Muitos negros, com a pele mais alva, quando se aproximou o fim da escravidão nos Estados Unidos, alisavam os cabelos para se passar por homens livres, buscando conseguir vantagens econômicas e sociais. Visto isso, muitas empresas de alisantes capilares surgiram e cresceram rapidamente visando atender um público que almejava obter técnicas e produtos mais seguros de alisamento. (QUINTÃO,2013)

No início do século XX, se popularizou nos Estados Unidos, entre os afro americanos, a técnica de alisamento com o pente quente - surgida primeiramente no século XIX, quando mulheres europeias usavam o pente quente para criar penteados - em 1968, os pesquisadores Philip LoPresti, M.D., Christopher M. Papa, M.D., e Albert M. Kligman, alertaram, depois de um estudo, que o uso desse objeto causaria inflamação e cicatrizes no couro cabeludo e, posteriormente, a alopecia em muitas mulheres. (AUSTIN, 2017)

Nos anos 70, principalmente com o movimento Black Power nos Estados Unidos, indo muito além de uma questão estética, os cabelos volumosos e naturais ganharam força ao romperam com o padrão liso, transcendendo para significados identitários e de afirmação. (VIEIRA, 2021) Apesar do movimento de contestação dos anos 70 e 80 , onde os cachos e crespos ganharam a cena, no início dos anos 90, voltou com força a moda dos cabelos lisos com uma técnica revolucionária que virou febre, - o alisamento japonês (ou escova definitiva) - ; já nos anos 2000, a indústria cosmética objetivando lançar produtos que permitissem 
cabelos menos volumosos e um liso chapado, difundiu o uso da escova progressiva, que tinha na fórmula o formol - uma substância controversa e que é considerada vilã pela classe médica por causar sérios danos à saúde -, nesse contexto, praticamente não havia esforços do mercado de beleza para atender as cacheadas e crespas. (BLUMARE, 2018)

Depois da implementação da cultura do liso no início século $\mathrm{XXI}$, nos últimos anos a sociedade tanto no Brasil como em outros países, passa por uma mudança radical no quesito de representatividade e aceitação dos fios naturais, o que fez com que muitas mulheres atravessassem pela transição capilar.

\subsection{Marcas para cacheadas e crespas}

As marcas possibilitam que os consumidores atribuam a responsabilidade pelo desempenho de certo produto para determinada empresa, bem como a fidelidade à marca estabelece previsibilidade, segurança de demanda e coloca barreiras para que outras empresas ingressem no mercado (KOTLER, KELLER,2012). Há diferenças significativas entre produto e marca como reflete Stephen King do grupo WPP de Londres:

\footnotetext{
"O produto é algo que é feito na fábrica; a marca é algo que é comprado pelo consumidor. O produto pode ser copiado pelo concorrente; a marca é única. O produto pode ficar ultrapassado rapidamente; a marca bemsucedida é eterna." (AAKER, 1998)
}

As consumidoras de produtos para cabelos têm hoje em dia a sua disposição um leque de opções de marcas que oferecem continuamente produtos com diferentes atributos e benefícios. Muitas empresas se dizem expert no segmento cacheado e crespo.

A autora a seguir alerta sobre os lançamentos desenfreados e da gama de possibilidades de produtos voltados para essa tipologia de fio, já que, segundo ela, muitas organizações não se prepararam e pesquisaram a fundo fórmulas para atender tal mercado. O risco há quando a consumidora adquire um produto que danifica o cabelo e que não atenda o mínimo das promessas de resultado. Então, no trecho abaixo ela exalta a marca Deva Curl, que acredita ter feito o caminho correto:

Essa rotina de cuidados surgiu de anos de pesquisa sobre como cuidar do cabelo cacheado, sobre substâncias que danificam e que salvam os cachos. A marca não foi 
simplesmente 'cuspida' no mercado para entender uma 'demanda inesperada', mas foi estudada, pensada, testada, avaliada, para assim entrar no mercado com integridade e qualidade. (GIAMPÁ,2016)

Para Quintiliano (2017), o lançamento do livro Curly Girl em 2007, O Manual da Garota Cacheada: o método curly girl, foi revolucionário para que as marcas tivessem uma nova perspectiva acerca de como atender esse público. Escrito pela cabelereira norte-americana Lorraney Massey, o livro tornou-se um guia de libertação para milhares de mulheres que queriam assumir os cabelos naturais, mas que não sabiam como fazê-lo. A obra popularizou as técnicas no poo e low poo no Brasil e no mundo, recomendando produtos liberados que são livres de parabenos e sulfatos na composição, além de estimular o fim do uso da chapinha e escova. Amaro (2012) aborda que Lorraney Massey fundou a marca Deva Curl, com apoio do público encaracolado e crespo e de um time de pesquisadores, isso foi possível após frustrar-se com os produtos que existia no mercado, pois os considerava ineficientes em seus próprios cachos, enxergando, assim, uma oportunidade de negócios e tornando-se pioneira no segmento.

No Brasil, tanto no desenvolvimento dos produtos como na comunicação com o público alvo, nota-se que desde 2014 as marcas lançam novidades constantemente. A Embelleze, por exemplo, começou naquele ano a focar no portfólio para esse público, alcançando 70 produtos, e tendo como carro chefe 0 creme de tratamento Novex Meus Cachos, além disso, mesclava a comunicação offiline e online, por meio do merchandising em novelas e programas de TV e, também, por intermédio das embaixadoras na comunicação dos seus produtos no meio digital. Em 2014, a Dove lançou a campanha "Love Your Curls", na qual apresentava meninas que sentiam vergonha dos seus cabelos encaracolados, porém, ao receber apoio de mulheres que já vivenciaram os mesmos problemas, conseguiam mudar de percepção, voltando com a autoestima e orgulhosas de possuir tais fios. Já a Seda, em 2015, desenvolveu o Seda Boom para cacheadas e crespas, com apelo jovem e comunicação alinhada com as Youtubers. (FRANQUILINO, 2017)

A marca Inoar há alguns anos foca em produtos liberados para as técnicas no poo, low poo e co-wash que, como já foi dito, é uma demanda das cacheadas e crespas; ganhando em 2017 o prêmio Alluere nos Estados Unidos por seu creme de pentear Divine Curls, dentre mais de 10.000 produtos concorrentes. Por fim, se destaca a Salon Line, que tem como ponto forte a linha \#todecacho, apesar da empresa estar há duas décadas no mercado brasileiro, foi com o segmento de 
cacheadas e crespas que ela ganhou fama nacional nos últimos anos; a forte presença digital e a proximidade com as consumidoras são estratégias que a fizeram crescer rapidamente e, ademais, as clientes participam ativamente na cocriarão, colaborando nas pesquisas prévias e no desenvolvimento dos produtos. (FRANQUILINO, 2017)

Conforme visto neste tópico, além das marcas já consolidadas, há muitas outras que estão aplicadas em atender essa demanda crescente. No presente estudo, não há o foco em alguma marca específica, porém, sim, nas tendências de comunicação e também na motivação das consumidoras.

\subsection{Comunicação das marcas}

A comunicação de Marketing visa informar, persuadir e lembrar os consumidores, de forma indireta ou direta, sobre os produtos ou marcas que as empresas comercializam. Sendo assim, a comunicação de marketing estabelece um relacionamento e diálogo com os consumidores, ao posicionar a imagem da marca na memória e criar uma imagem dela, colaborando com a formação de brand equity e customer equity. (KOTLER; KELLER,2012)

Identidade, posicionamento e imagem estão intrinsicamente ligados. Portanto, a percepção e as impressões do consumidor em relação ao posicionamento e identidade da empresa resultam numa imagem formada da marca. Comunicação e estratégia de posicionamento desempenham papel fundamental na construção dessas impressões. Alguns elementos que fazem parte da formação da identidade da marca - como os seus valores e suas ofertas - podem ser comunicados por meio de peças publicitárias e, com isso, num comercial de creme de tratamento pode haver, por exemplo, uma enfatização na mensagem de sustentabilidade, saúde e autoestima. (TAVARES, 2008)

O autor também salienta que os clientes mais suscetíveis à comunicação da marca são aqueles que não tiveram ou tiveram pouca experiência com os produtos e serviços da organização, como confirmado a seguir.

À medida que o cliente adquire experiência com a marca e com a empresa, a comunicação passa a ter um papel diferenciado, ajudar a mantê-lo, informando sobre as inovações e mudanças nos produtos e serviços. Quando há diferença entre o conteúdo da mensagem publicitária e a experiência, o cliente tenderá a acreditar mais na experiência e menos na mensagem. A comunicação e a experiência devem, assim, ser as principais fontes na construção desses significados. (TAVARES, 2008, P.194) 
"O composto de comunicação combina quatro diferentes elementos para criar a estratégia geral da comunicação de marketing: propaganda, vendas pessoais, promoção de vendas e publicidade." (CHURCHILL; PETER ,2010, p. 452) Promotores que auxiliam os clientes nas lojas físicas sobre as características dos produtos, pontuando seus benefícios e atributos, é um tipo conhecido de venda pessoal, na qual as marcas cosméticas de cabelo contratam profissionais especializados, visando recomendá-las aos clientes que se deslocam até o ponto de vendas. Em contrapartida, a comunicação por intermédio das promoções de vendas tem como alvo as clientes mais sensíveis a preços, incluindo descontos por tempo limitado, brindes, amostras grátis e ofertas do tipo leve dois pague um.

A publicidade tem fins estritamente comerciais, atingindo e engajando o público para venda de marcas, empresas, produtos e serviços, diferentemente do tipo anterior, a propaganda é não paga, sendo a responsável pela propagação de ideias, inclusive, oriundas dos governos e instituições religiosas. (WAGNER, 2021)

A comunicação na presente pesquisa é calcada no tripé: fonte, mensagem e meio, que serão estudados nos subtópicos abaixo:

\subsubsection{Estratégia de fonte}

A fonte é o início da comunicação. Um comunicador pode mudar as atitudes de um consumidor, pois características do porta-voz de uma marca, como credibilidade e atratividade, tornam-se decisivas para que o receptor tenha motivação no que tange o processamento da mensagem.(SOLOMON, 2016) Também Kotler e Keller (2012), corroboram com a linha de pensamento do autor anterior, ao destacar o domínio do assunto, que é o conhecimento especializado que a fonte possui para embasar os argumentos, isso demonstra credibilidade do comunicador, fazendo com que ele consiga influenciar o público-alvo.

Conforme os autores supracitados, as marcas se utilizam do endosso das fontes para passar credibilidade dos seus serviços e produtos aos consumidores. Fazendo um paralelo com as marcas de cabelos cacheados e crespos, é visto, nos últimos anos, a estratégia de endossamento por meio das influenciadoras digitais. 
Borges (2016) afirma que as chamadas "blogueiras" conseguiram ganhar atenção das marcas, uma vez que são ícones da moda e de comportamento e, como consequência, conquistam cada vez mais espaços e investimentos nos veículos de comunicação. As blogueiras tornaram-se fontes de inspiração para alguns nichos, são verdadeiras formadoras de opinião e, agora, elas são designadas pelo termo digital influencers. Conforme a autora a seguir:

Estar próximo ao seu público sempre foi o desejo de diversas marcas. Procurar formas para que isso ocorra também faz parte dessa busca, e uma delas por muito tempo foi a de ter "Garotas-propagandas", a utilização de pessoas famosas que fossem a "cara" dessa marca. Com o surgimento dos influenciadores digitais estamos vivenciando uma mudança nesse panorama. (LINO, 2016, p. 27)

As influenciadoras digitais conseguem estabelecer um diálogo próximo ao público, entendendo suas emoções e suas preferências. Dessa mesma forma, as empresas também buscam assimilar as experiências, gostos e emoções do seu público-alvo para melhor adequar e direcionar seus produtos e conteúdo.

As marcas designam o termo embaixadora ao escolher pessoas que as representem em mídias digitais, eventos, dentre outros. O rosto oficial da marca é escolhido com base em alguns critérios como: análise do comportamento dessa personalidade dentro e fora das mídias sociais; seu público real e engajamento nas plataformas; se tem estilo/perfil que a empresa necessita; percepção do público em relação a imagem dela e, por fim, seu alinhamento com o posicionamento e identidade da marca. (DINO at al, 2021)

As influenciadoras se comunicam por meio de textos, fotos e vídeos em suas redes sociais, já os seguidores ficam alerta a novas postagens, pois buscam saber o posicionamento que elas tomarão diante das marcas e novos produtos. Resenhas em blogs e no YouTube, posts patrocinados no Facebook e Instagram são formas de comunicar novidades e lançamentos de produtos, sendo uma importante fonte de informação no processo de decisão de compra de muitos consumidores, que nessa etapa, analisam as diversas opções disponíveis no mercado.

Segundo Stupp (2019), o IBGE realizou um estudo no qual constatou que $59 \%$ dos internautas que seguem algum influenciador digital são mulheres; $27 \%$ dos internautas procuram assuntos relacionado à beleza, além disso, quando se trata de comportamento de compra; $50 \%$ dos internautas costuma comprar de 
acordo com a indicação dos influenciadores, e que, 56\% desses consumidores são mulheres.

Já em relação ao uso de celebridades em comercias de TV, por exemplo, em um cenário ideal, os anunciantes procuram definir os significados que o produto pretende transmitir e, logo em seguida, utilizam uma celebridade - que incorpora um significado semelhante - como forma de veículo. (SOLOMON, 2016)

\begin{abstract}
"O poder de atração das pessoas famosas pode até estar "programando": um estudo descobriu que, em comparação com rostos "comuns", nosso cérebro presta maior atenção aos rostos famosos e processa mais eficazmente as informações sobre essa imagem." (SOLOMON, 2016, p.322)
\end{abstract}

As celebridades têm o poder de melhorar as atitudes do consumidor em relação às marcas, por isso as empresas investem altos valores nesse tipo de fonte de comunicação. Cantores, modelos, esportistas, escritores e outras pessoas com grande visibilidade na mídia são reconhecidas por terem grande capacidade de transferir valores e credibilidade para as marcas, de conseguir a atenção das pessoas mesmo diante da disseminação de propagandas, ofertas e de canais de mídias. (ANDRADE, 2008)

A publicidade destinada às mulheres de cabelos cacheados e crespos passou por uma significativa mudança ao longo dos últimos anos, antes não se via comerciais de TV destinado a esse público, tampouco havia famosas com esta estrutura de fios em peças publicitárias. Atrizes como Débora Nascimento, Jeniffer Nascimento e Sheron Menezes viveram essa realidade na infância ao não se sentirem representadas pelas empresas, mas hoje são estrelas de marcas como Seda, Niely e Pantene. (EXTRA, 2017)

A seguir, a atriz Jeniffer Nascimento comenta sobre a falta de representatividade de propagandas e produtos específicos para cabelos cacheados e crespos:

Nunca, na minha infância, que eu imaginaria fazer propaganda de produto de cabelo! Isso era muito distante da minha realidade. Estou vivendo quase a realização de um sonho de menina - diz Jeniffer Nascimento, a Tânia de "Pega pega", que é uma das cocriadoras da linha Diva de Cachos, da Niely. (EXTRA, 2017)

Dessa forma, a utilização tanto de famosas quanto de anônimas para a representação das marcas, tem como ponto chave, a escolha de pessoas que 
sejam, de alguma forma, próximas ao público alvo, em experiências, em suas emoções e também visualmente.

\subsubsection{Estratégia de mensagem}

Para Kotler e Keller (2012, p.519), "Ao determinar a estratégia de mensagem, a gerência deve procurar apelos, temas ou ideias que se conectem ao posicionamento da marca e ajudem a estabelecer pontos de paridade e pontos de diferença". Para estabelecer um envolvimento com a consumidora a partir da mensagem, as marcas utilizam diferentes tipos de apelos em sua publicidade $e$ propaganda a fim, muitas vezes, de estabelecer um vínculo emocional com o público-alvo.

Para o presente estudo, há a abordagem da estratégia criativa que pode ser categorizada em apelos informativos e transformacionais. (KOTLER; KELLER, 2012) Conforme será visto a seguir, o enfoque do estudo é o apelo transformacional:

Apelos Transformacionais: $O$ apelo transformacional tenta estimular as emoções que motivaram o consumidor a comprar, baseando-se em benefícios e imagens que não tem ligação com o produto. Os comunicadores tentam envolver o consumidor com o anúncio por meio de apelos emocionais positivos, como amor, orgulho, alegria e humor, assim como apelos negativos, como medo, culpa e vergonha.

Marcas como a Salon Line e Seda, tal como outras do nicho de cachos e crespos, visam difundir mensagens de valorização dos cabelos naturais, além de bandeiras como empoderamento feminino e autoestima. Outras marcas como a Soul Power, além desses aspectos já citados, frisam na questão da sustentabilidade, ou seja, em produtos que respeitam o meio ambiente, que sejam veganos e não testados em animais. A seguir há duas figuras: o manifesto da Soul Power com termos como "cruelty free", "100\% FREE FROM", "livre de substâncias prejudiciais à saúde", "Somos Veganos" e, logo após, uma imagem sobre uma campanha de diversidade da Seda.

uma campanha de diversidade da Seda. 


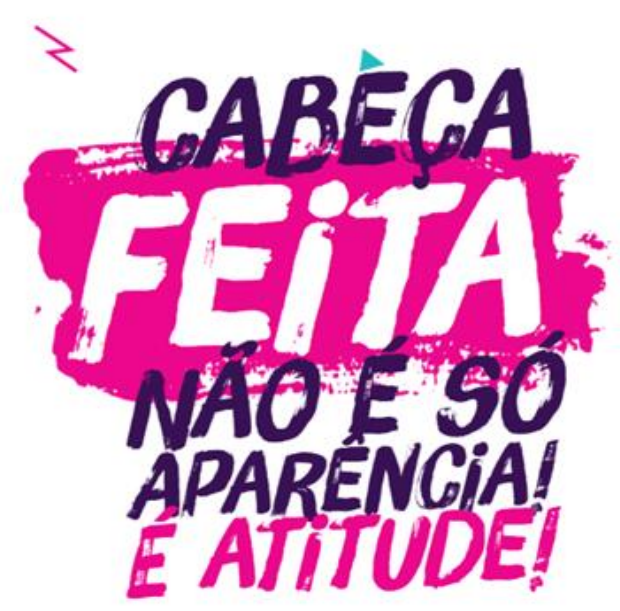

Fonte: Disponível em: https://soulpower.com.br/manifesto

\begin{abstract}
Se os seus cabelos são crespos, ondulados ou cacheados, a primeira coisa que você deve saber é que você é linda e sempre foi Cabeça feita. E a SOUL POWER é para quemé ć cabeça feita. E o que isso quer dizer? Beleza, atitude, autenticidade e poder. Do ondulado ao crespo. Nossa marca, assim como você, conhece bem as alegrias, os cuidados, os mistérios e os dilemas que seus fios têm.

Cabeça feita nāo tem pele ou cor. Somos brasileiros, miscigenados, misturados. Levamos nossa beleza aonde for. E outra coisa que a gente leva e leva à sério é o respeito. Respeito ao meio ambiente, ao mundo, a vocé. Somos veganos, cruelty free e livre de substáncias proibidas ou prejudiciais à saúde. 100\% FREE FROM. Faz bem, é bom.

Nascernos com o desafio de atender a todos os tipos de curvaturas. Estamos aonde estão as Cabeças feitas para chegar aos coraçōes de todos os brasileiros. Até porque temos paixão por cabelos. Mais precisamente pelos seus. Naturais. com vida e todas as voltas que dá. Eles preenchem a nossa existência e, por eles, viemos para ficar.

Soul é alma. Power é poder. Uma nova linha de produtos inspirada em vocé.
\end{abstract}

Figura 2: Campanha sobre diversidade com influenciadoras da Seda

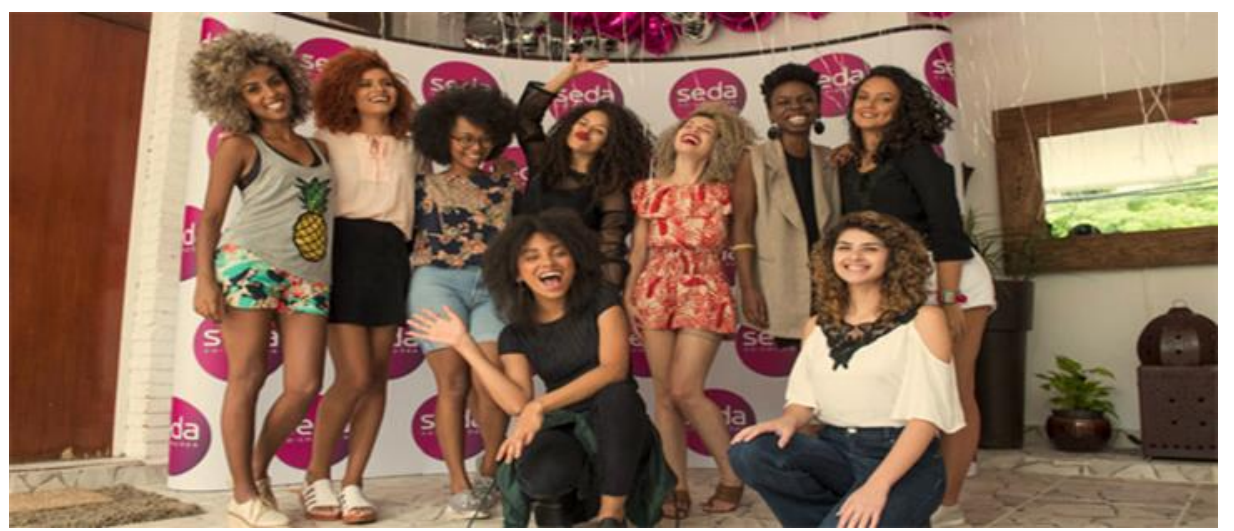

Fonte: $\quad$ https://noticias.ambientebrasil.com.br/divulgacao/2019/10/13/154604-nielsen-produtossustentaveis-de-higiene-beleza-crescem-em-consumo-e-aumentam-participacao-no-faturamento-daindustria.html

O consumidor busca informações a respeito dos valores e posicionamento das marcas sobre algumas pautas da sociedade, desse modo, as empresas se comunicam por meio de mensagens que apelam para a emoção de acordo com as motivações das clientes. Como diz Inocência Manoel, fundadora da INOAR, sobre temas como valorização e sustentabilidade.

No que diz respeito ao potencial de crescimento do segmento, ela destaca o caráter "libertador" do movimento de valorização dos cabelos crespos e cacheados e que a tendência é de fortalecimento desse mercado, que deve aumentar o investimento em ingredientes botânicos. "O mesmo consumidor que busca liberdade para definir seu look é o que quer saber o que existe dentro da embalagem. 
Não testar em animais e não utilizar produtos de origem animal, é tão importante quanto ter liberdade de escolha", acredita. (FRANQUILINO, 2017)

. Reforçando o pensamento anteriormente citado, o movimento verde é uma preocupação real do consumidor, destacando-se a população vegetariana e vegana, que busca um estilo de vida mais saudável e se preocupa cada vez mais com o futuro do planeta. O Ambiente Brasil (2019) divulgou o estudo Green is the New Black da Nielsen Brasil, que revelou três categorias de produtos sustentáveis: produtos que não são testados em animais, veganos e com ingredientes naturais. Shampoo e condicionador são preferências na compra de produtos sustentáveis no segmento de cosmético e higiene pessoal, representando respectivamente $29,9 \%$ e $22,5 \%$, conforme apresentado no gráfico a seguir.

Figura 3: Gráfico consumo de produtos sustentáveis

\section{CONSUMIDOR AFIRMA QUE CATEGORIAS SUSTENTÁVEIS MAIS COMPRADAS SÃO SHAMPOO, PÓS SHAMPOO E SABONETES}

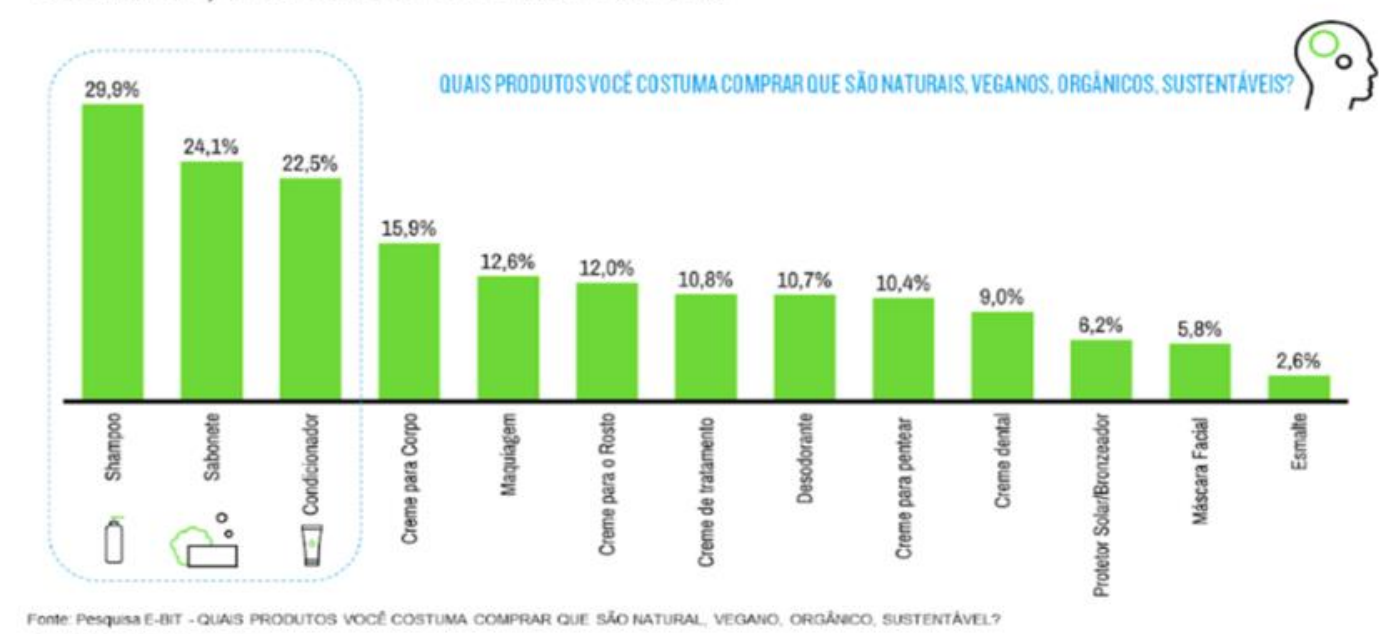

capport o 2019 me tiesen conpary

Fonte: $\quad$ https://noticias.ambientebrasil.com.br/divulgacao/2019/10/13/154604-nielsen-produtossustentaveis-de-higiene-beleza-crescem-em-consumo-e-aumentam-participacao-no-faturamento-daindustria.html

De acordo com uma pesquisa da Mintel de 2017, 29\% dos brasileiros preferem comprar de empresas com práticas sustentáveis; além disso, um levanto da Kantar Worldpanel 2018, mostrou que 50\% dos consumidores escolhem produtos com ingrediente de origem natural quando se trata de cuidados pessoais. (ABIHPEC, 2018) Pelo mesmo relatório, o assunto diversidade ganha destaque, ao enaltecer temas como valorização do natural e empoderamento das mulheres. 
Conforme os dados supracitados, diversas marcas já vislumbraram uma oportunidade em tais temas e já implementam o apelo ao orgulho e o apelo ao medo (negativo) em suas mensagens nas propagandas, respectivamente para diversidade e sustentabilidade. A primeira ao enaltecer a autoestima, ao incentivar que as mulheres assumam seus fios naturais, ao escolher mulheres reais para comunicar seus produtos e mostrar para o público como são diversos os tipos de cabelos.

A segunda pode, por exemplo, passar uma mensagem em suas peças publicitárias do quanto é benéfico a utilização de produtos que não agridam a natureza; por meio do marketing verde, ou seja, "atividades de marketing destinadas a atender ao desejo dos clientes de proteger o ambiente." (CHURCHILL; PETER ,2010, p. 44)

Figura 4: Selos Cruelty Free e Vegano
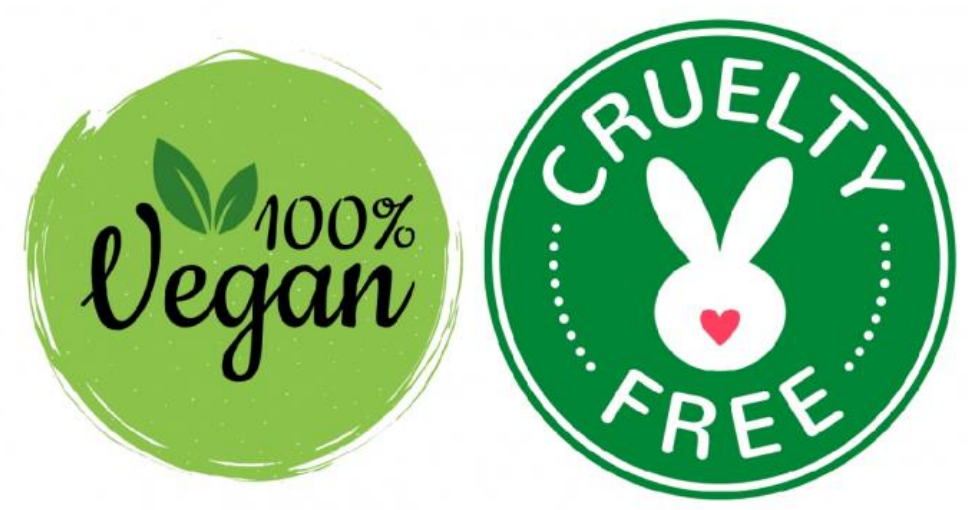

Fonte: https://www.purebreak.com.br/noticias/marcas-veganas-x-cruelty-free-entenda-a-diferenca-eveja-opcoes $/ 98070$

Marques (2021) estabelece a diferença entre os termos vegano e cruelty free, que são amplamente inseridos no vocabulário das cacheadas e crespas, o selo cruelty free nas embalagens significa que a marca não realiza testes em animais, assim como também toda a cadeia produtiva na qual a marca pertence também não pode utilizar-se destes testes; já os produtos veganos não têm nada de origem animal em sua composição, assim, tais itens pertencem às marcas cruelty free. 


\subsubsection{Meios de Comunicação}

"Os profissionais de marketing devem empenhar-se em achar o composto de comunicação mais eficaz e eficiente, levando em conta as vantagens e desvantagens de cada tipo de comunicação." (CHURCHILL; PETER ,2010, p. 452)

Cada veículo possui suas vantagens e desvantagens, e a mídia ou composto de mídias mais apropriado para um produto pode não ser satisfatória para outro.

O objetivo dessa escolha é atingir o público-alvo e, assim, obter um retorno positivo. Existe uma variedade de mídias que as empresas podem utilizar em sua estratégia, tais como: TV, rádio, internet, revistas ou jornais. Para o presente estudo há o foco nas mídias digitais.

Com o advento da pandemia da Covid-19, aumentou expressivamente o número de pessoas conectadas à internet e que acessam frequentemente as mídias sociais. Ainda em 2019, uma pesquisa da TIC domicílios, que realiza levantamento sobre acesso à tecnologia da informação e comunicação, revelou que $90 \%$ das pessoas acessam a internet todos os dias; $76 \%$ utilizam redes sociais como Facebook e Instagram e que as informações mais buscadas foram sobre produtos e serviços, 59\%. (VALENTE, 2020)

De acordo com o especialista em Marketing Wesley de Freitas Pimentel, "o marketing digital ganhou destaque nas plataformas sociais como Facebook, Instagram, YouTube e Tiktok, que passaram a ser vistas com uma maior perspectiva para divulgação de negócios, produtos e serviços." (DINO,2021) O especialista complementa dizendo:

\footnotetext{
"Hoje são consideradas as melhores formas de divulgação existentes, comparadas com 10 ou 20 anos atrás, quando a televisão e o rádio eram os meios mais efetivos para atingir o público desejado. Esse fenômeno atingiu, inclusive, o âmbito da política, a qual foi explorada nas últimas eleições presidenciais. Visto que foram definidas majoritariamente nas redes sociais", declara Pimentel, com MBA Business Management. (DINO,2021)
}

Para Lino (2016), na estratégia de comunicação há a definição de quais ferramentas que serão utilizadas e a melhor maneira de aplicá-las, sendo assim, a visão do público em relação à empresa é que definirá o melhor curso a ser percorrido no meio digital. Visto isso, o engajamento do público nas redes sociais da organização é considerado o "termômetro" para avaliar conteúdos, produtos e 
serviços oferecidos, ou seja, é uma fonte de informações a respeito de como o consumidor quer ser tratado e quais relações almejam nas redes. Por fim, identifica se a percepção do consumidor está condizente com a imagem que a empresa quer transmitir.

Paro Patel (2021), "mídia digital é todo conteúdo ou veículo de comunicação que se baseia na internet e a utiliza como meio de distribuição", ao contrário da mídia tradicional ou analógica em que o processo de comunicação é unilateral, a mídia digital tem como característica a interatividade, ou seja, há a possibilidade de o receptor fornecer feedback. O consumidor, na mídia digital, tem a liberdade de opinar, reclamar, criticar, recomendar, responder e chega até mesmo a criar seu próprio conteúdo. Borges (2016) afirma que o consumidor atual é empoderado e que o universo do marketing e propaganda surpreende constantemente com novidades estratégicas que propiciam uma maior ligação das marcas com o cliente e seus respectivos produtos.

O autor Gabriel et al (2010), divide a mídia digital em três categorias: própria, ganha e paga. A primeira é considerada a mais importante e tem como vantagem custar menos do que a paga, dado que se trata de toda e qualquer mídia controlada pela organização, como seus sites, blogs e redes sociais. A segunda é a preferida dos profissionais de marketing e sonho de toda marca, já que se trata do conhecido boca a boca online, sendo gratuita, a referida mídia transforma o cliente em divulgador da empresa. E, finalmente, a terceira está fortemente relacionada a publicidade e propaganda, na qual a marca paga um valor financeiro em troca de conseguir um alcance digital, com isso, busca obter fidelização do cliente e vendas, alguns dos exemplos são os anúncios Google e Facebook Ads.

Segundo Volpato (2021), o relatório de outubro de 2020 por We are Social e Hootsuite revelou as redes sociais mais seguidas do Brasil: o Facebook fica em primeiro lugar com 130 milhões de contas ativas no país, logo em seguida aparecem Whatsapp, YouTube e Instagram.

Dentre as redes sociais citadas, o YouTube se destaca por ser uma ferramenta poderosa para cacheadas e crespas; local que difundiu conhecimento e termos técnicos como: finalização, day after, big chop, low poo/no poo, transição capilar, co-wash, cronograma capilar além de muitos outros. O Dossiê BrandLab: A Revolução dos Cachos (2017) constatou a importância desse meio para o público feminino que segue uma rotina capilar, como mostra a figura seguir: 
Figura 5: Estatísticas do YouTube em relação às cacheadas e crespas

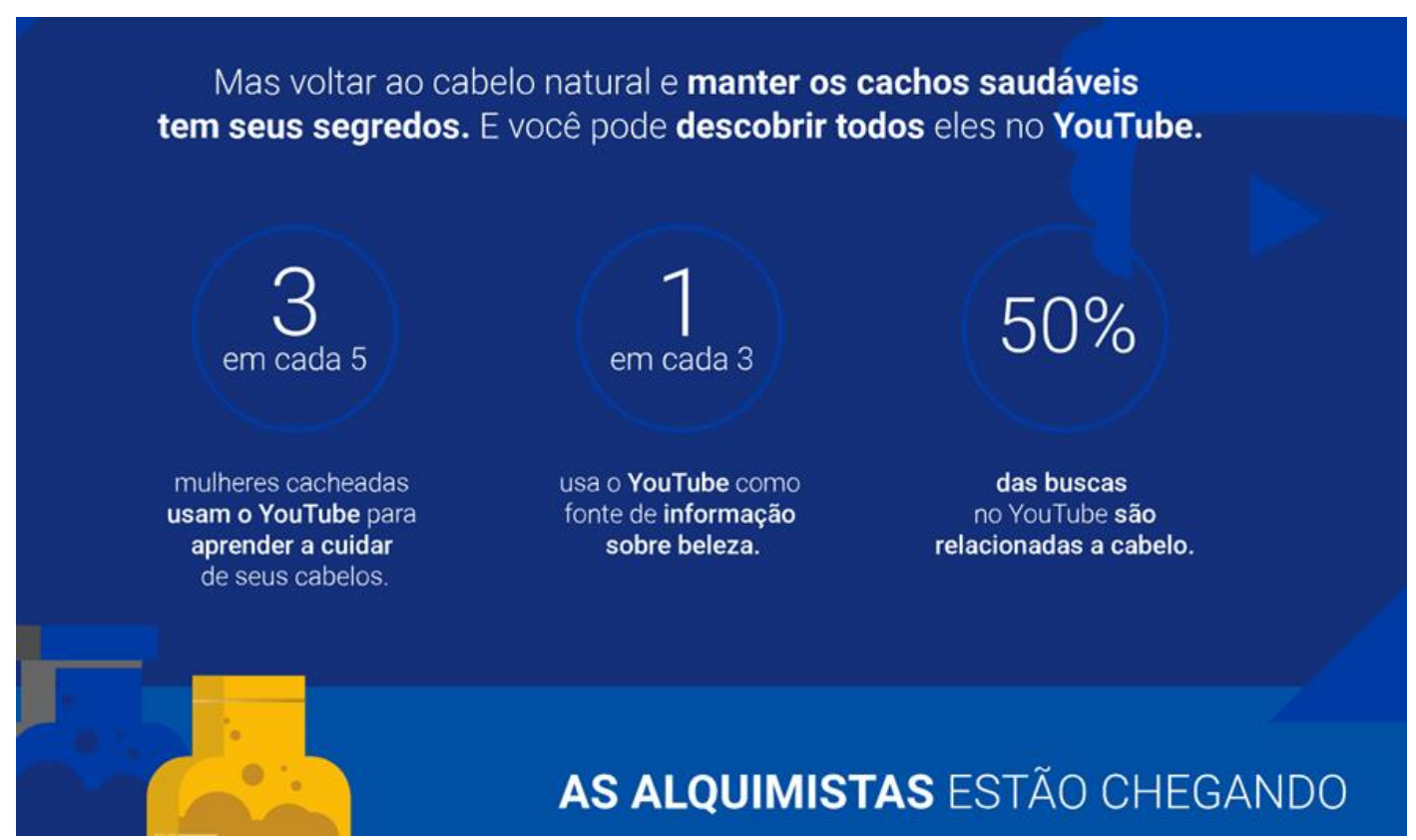

Fonte: https://www.thinkwithgoogle.com/int/pt-br/estrategias-de-marketing/video/revolucao-dos-cachos/

À medida que as mídias sociais ganham importância como estratégia de comunicação, os consumidores se tornam, de forma progressiva, influenciadores de outros consumidores, posto que eles podem compartilhar suas opiniões e experiências. A tendência é que a influência da propaganda corporativa no comportamento do consumidor diminua na mesma proporção. (KOTLER; KELLER, 2012)

Muitas marcas de cabelos cacheados e crespos têm como estratégia principal a atuação digital visando conquistar um público cativo, engajado e, até mesmo, que acaba se tornando fã. No entanto, apesar do exposto a respeito da importância da atuação por esse meio, vale destacar, que ainda há a necessidade de integração dos meios digitais com os tradicionais, o que representa um verdadeiro desafio a ser superado pelas organizações.

\subsection{Motivações das consumidoras}

Além da comunicação já analisada até aqui, outro tema central do trabalho consiste em estudar as motivações das consumidoras. Assimilar o conceito de motivação é indispensável para o entendimento do comportamento do consumidor.

A motivação está ligada à necessidade e ao desejo, este se refere à necessidade que é satisfeita de forma especial e diferenciada, baseado em fatores culturais e pessoais. Sendo assim, uma pessoa que queira tratar o cabelo pode comprar os produtos e aplicá-los sozinha em casa; ou, para realizar o desejo de 
ter um tratamento customizado, pode contratar os serviços de um Spa Capilar, por exemplo. Além disso, motivação ocorre quando há o despertar da necessidade em um consumidor, e este busca meios para satisfazê-la. (SALOMON, 2016) A motivação é o impulso interior de uma consumidora para satisfazer uma necessidade ou desejo.

O conceito acima citado complementa a Teoria da Hierarquia das Necessidades do psicólogo Abraham Maslow, na qual ele afirma que o indivíduo, seja para o campo pessoal ou profissional, começa a suprir suas necessidades da base da pirâmide, que é o nível da sobrevivência, e vai percorrendo estágios conforme os níveis anteriores vão sendo atendidos, em direção ao topo. Essa teoria é bastante questionada pelos pesquisadores, por não possuir comprovação empírica, contudo, ela é amplamente utilizada pelos profissionais de marketing, já que é abordada algumas das necessidades que motivam os consumidores. (CHURCHILL; PETER, 2010) A pirâmide apresenta cinco níveis: fisiológica, segurança, social, estima e realizações pessoais.

$>$ Fisiológica: "ter o cabelo limpo e cheiroso".

> Segurança: "comprar produtos que tenham ingredientes que não agridam o cabelo, sem química ou sem substâncias fortes (como sulfatos e parabenos)".

$>$ Social: "ter produtos de marcas que promovam a diversidade em sua comunicação, com mulheres reais e diversos formatos e tipos capilares".

> Estima: "ter a autoestima elevada ao ver um resultado positivo de uma hidratação nos fios ou ao receber um elogio sobre a aparência do cabelo".

$>$ Realizações Pessoais: "se sentir contribuindo com o meio ambiente por não comprar produtos que agridam a natureza; ter o sentimento de dever cumprido".

As marcas que se concentram apenas na base da pirâmide atingem principalmente o lado mais racional do cliente e, para se diferenciar, é importante que as organizações tenham um olhar mais apurado para o topo, no qual, o lado emocional do público alvo é mais sensível e difícil de decifrar, dado a sua subjetividade. 


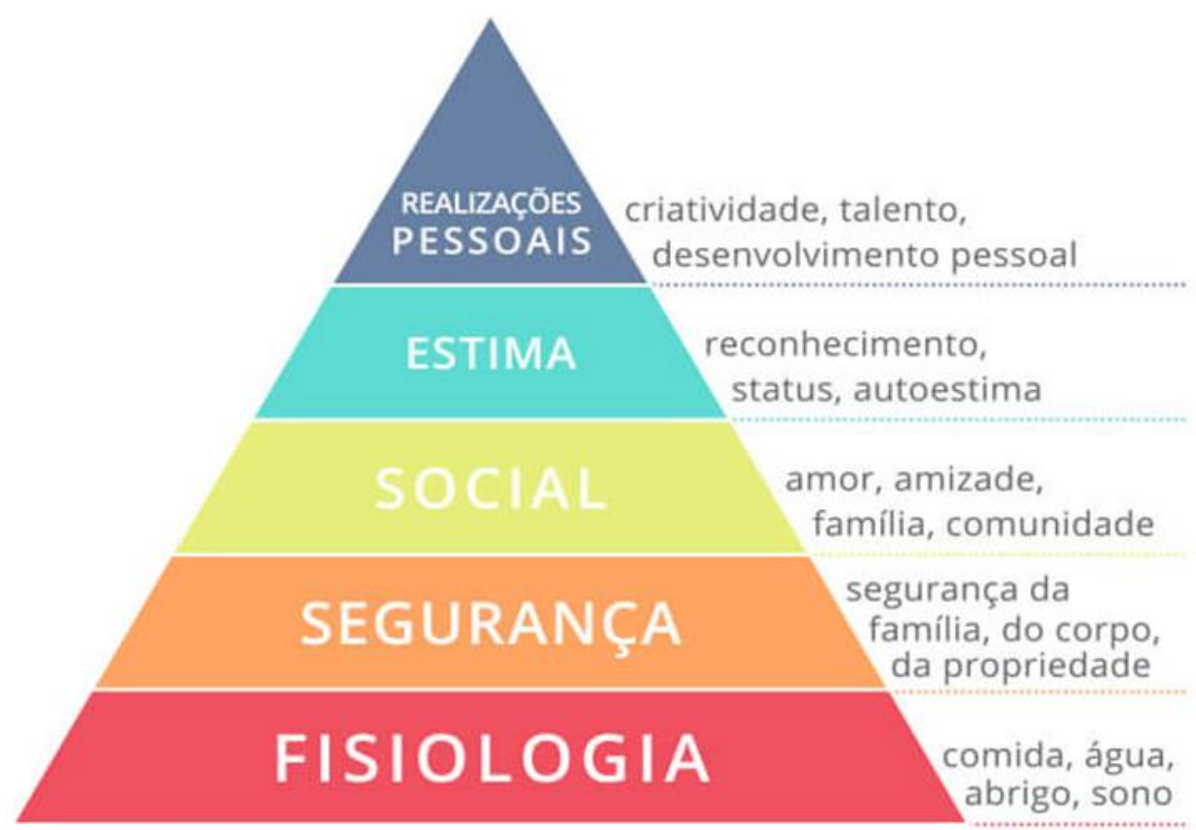

Fonte: https://blog.opinionbox.com/piramide-de-maslow/

A dinâmica do processo de motivação começa no momento em que se tem o reconhecimento e ativação da necessidade, sendo que ela é ativada e sentida quando há discrepância suficiente entre o estado desejado ou almejado de ser e o estado real; com isso, a condição de impulso é despertada como consequência do aumento da discrepância. (BLACKWELL; MINIARD; ENGEL, 2000) "Quanto mais forte o impulso, maior a urgência percebida de resposta. Profissionais de marketing alertas farão todo o possível para promover produtos e serviços que sejam eficazes para a redução deste estado de despertar." (BLACKWELL; MINIARD; ENGEL, 2000, p.267)

Segundo Solomon (2016, p.39), "O envolvimento reflete nosso nível de motivação para processar informações sobre um produto ou serviço que acreditamos que nos ajudará a solucionar um problema ou atingir uma meta". De acordo com Blackwell, Miniard e Engel (2000, p. 106) "O grau de envolvimento pessoal é o fator mais importante que molda o tipo de comportamento de processo decisório que será seguido". 
Figura 7: Envolvimento = $\mathrm{f}($ pessoa, situação e objeto $)$

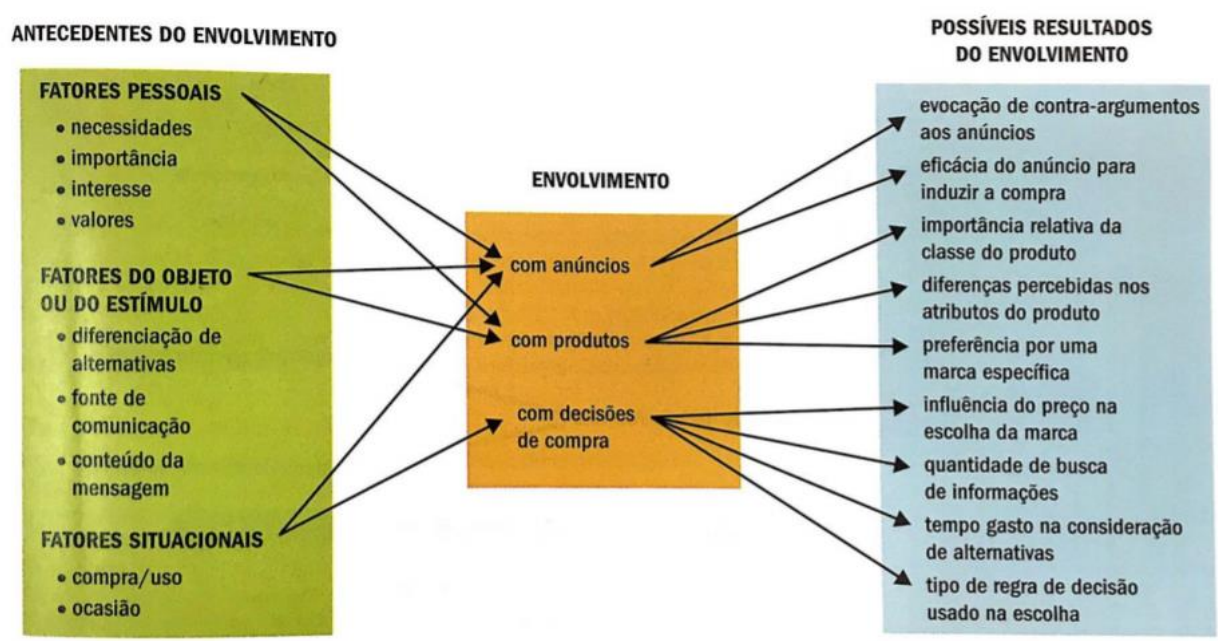

ENVOLVIMENTO $=f($ pessoa, situação, objeto $)$

Fonte: Solomon (2016, p.39)

Envolvimento com a mensagem: (p.43) "os veículos de comunicação (ou veículos de mídia) têm qualidades diferentes que influenciam nossa motivação para prestarmos atenção no que eles dizem...", como já foi visto nos tópicos de comunicação do estudo, há diferentes estratégias de mensagem para criar envolvimento com o público de cabelos cacheados e crespos. Outrossim, o autor relaciona o nível de envolvimento com as mídias existentes. Mídia impressa é considerada de alto envolvimento, pois ao ler uma resenha em um blog, o consumidor pode processar as informações e parar para refletir sobre o assunto do texto. Por outro lado, a TV é um meio de baixo envolvimento, já que demanda um telespectador passivo que tenha um controle mesmo que pequeno sobre 0 conteúdo.

Envolvimento situacional: (p.44) "O envolvimento situacional tem lugar na loja física, no site ou no local que as pessoas consomem produtos ou serviços." Um determinante situacional ocorre por um período específico de tempo e permanece assim durante a existência da situação que o desencadeou. 
> Envolvimento com o produto: "é o nível de interesse do consumidor por um produto específico." Na visão de Solomon (2016), o envolvimento aumenta na medida em que as empresas conseguem criar um vínculo da marca com o indivíduo, assim sendo, o envolvimento tende a crescer quando o consumidor consegue ter a percepção do risco em adquirir um produto. "Quando um consumidor está altamente envolvido com um produto específico, isso representa uma relíquia para as empresas porque significa que ele demonstra lealdade à marca..." (SOLOMON, 2016, p.42)

\subsection{O processo de compra}

No presente capítulo, há a descrição do processo cognitivo da tomada de decisão defendido por Solomon (2016), por sua vez, o autor salienta a importância das perspectivas habituais e afetivas das escolhas do consumidor.

Outro ponto enfatizado pelo autor supracitado, diz respeito ao afeto e a forma como este influencia no comportamento do consumidor, pois quando uma pessoa está motivada há uma série de sentimentos, emoções e humores relacionados às decisões de compra. (BLACKWELL; MINIARD; ENGEL, 2000) Já Solomon (2016), destaca o esforço cognitivo no processo de decisão de compra, que liga a abordagem racional bem pensada e a capacidade mental para as escolhas em relação a um produto. 
Figura 8: Processo de decisão de compra

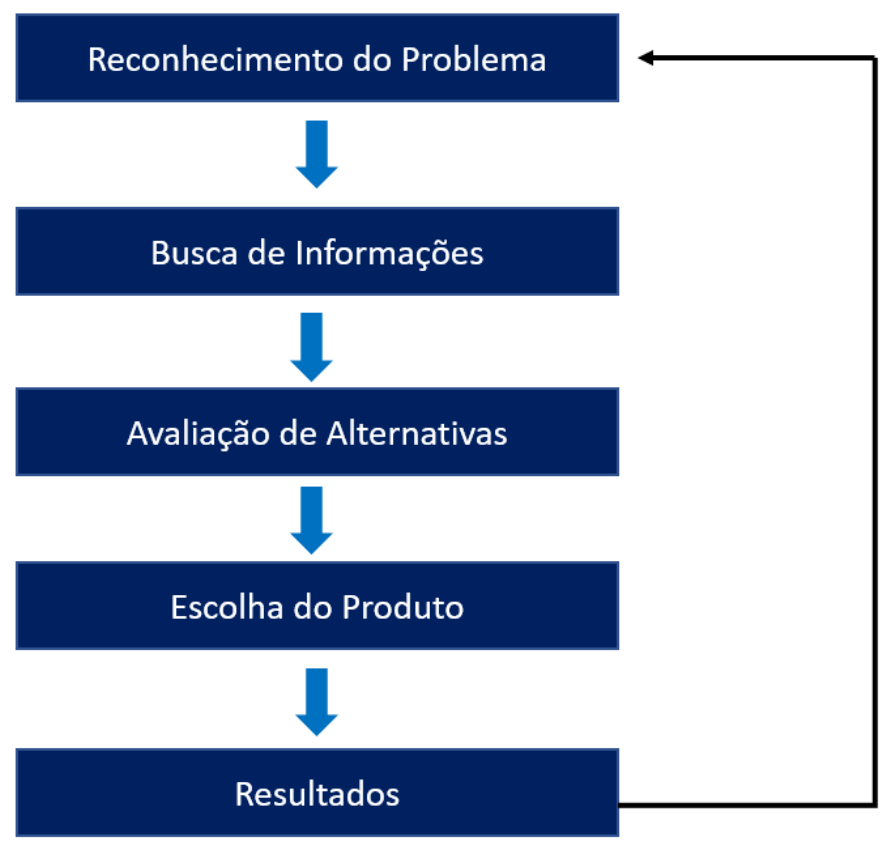

Fonte: Adaptada de Solomon,2016, p. 48

Reconhecimento do problema: o reconhecimento de um problema que requer uma solução, ocorre quando o indivíduo constata uma discordância considerável entre o estado ideal e o estado real em dada situação. Por exemplo: Lúcia percebe que sua linha de produtos para tratamento capilar está acabando, tais produtos não corresponderam suas expectativas, então, ela começa a procurar uma nova marca.

Busca de Informações: a busca interna de informações se dá por meio da memória do consumidor, ao lembrar das opções disponíveis no mercado. E esse grau de conhecimento corrobora com a pesquisa externa para a escolha da melhor alternativa. Por exemplo: Lúcia, começa a assistir vídeos no YouTube em busca de avaliações sobre determinada linha de produtos. Churchill e Peter (2010) destacam alguns tipos de fontes que auxiliam o consumidor na seleção das marcas para escolha do produto, que são os seguintes: de grupos (amigos e familiares); de marketing (vendedores, propagandas, mostruários, embalagens etc); públicas (artigos na mídia); de experimentação (consumidores que experimentam o produto no local de vendas). Um levantamento da Buzzlead (2017) sobre uma pesquisa da Nielsen mostrou que, 92\% dos clientes em todo o mundo confiam plenamente em amigos e familiares para recomendação de compras, muito mais do que qualquer outro tipo de propaganda. Bentivegna (2002) em seu estudo sobre impacto do marketing boca a boca online, revela que 
uma das principais vantagens desse tipo de fonte é a sua imparcialidade e a objetividade, uma vez que ela não tem ligação comercial com a empresa do produto e, por consequência, a informação advinda do contato pessoal ganha maior credibilidade.

Avaliação de Alternativas: consiste na identificação e avaliação das alternativas de marcas, levando em consideração características, recursos e atributos particulares no julgamento da escolha. $O$ consumidor opta pela compra que Ihe trará maior valor agregado. Por exemplo: Lúcia seleciona as marcas que oferecem preços que cabem em seu orçamento e que tenha produtos com ingredientes liberados para a técnica low poo. Blackwell, Miniard e Engel (2000) salienta alguns fatores de critérios de avaliação, sendo eles: segurança, confiabilidade, preço, país de fabricação e, também, de natureza mais hedonista (como sentimento em relação a determinada marca)

Escolha do produto: "Depois de considerar as opções possíveis, os consumidores podem fazer uma compra. Essa etapa de decisão da compra inclui decidir fazer ou não a compra e, no primeiro caso, o que, onde, quando comprar e como pagar." (CHURCHILL; PETER, 2010, p.150) Por exemplo: Lúcia decide comprar uma marca indicada por uma amiga e, para ter certeza a respeito dessa decisão, antes ela assistiu algumas resenhas desses produtos por vídeos na internet, ao gostar do resultado no cabelo de quem estava testando, o último passo foi a finalização da compra pelo site da empresa.

Resultado: Após a compra, há a experimentação do produto ou serviço, como consequência o consumidor obtém as impressões e conclui se tal produto atendeu às expectativas. Esse processo gera a satisfação/insatisfação do consumidor. Para o mercado de produtos para cacheadas e crespas, atualmente, nota-se o grande número de marcas e, cada vez mais, a concorrência se acirra, diante disso, atender às expectativas do consumidor em relação aos produtos e provocar uma recompra é muito importante para o desempenho do negócio. Assim denota que o comprador tem satisfação no uso dos produtos adquiridos, servindo como medidor de atração e retenção dos clientes. Santos (2020) esclarece que a fidelização do cliente é de extrema importância diante dos momentos de crise e do acirramento do mercado, clientes fiéis podem ser monitorados por meio da taxa de recompra na qual a empresa calcula quantos clientes que tiveram uma boa experiência de compra em um determinado período e retornaram para realizar novas aquisições. 
Essa última etapa do processo decisório traz informações relevantes sobre o comportamento futuro do consumidor, uma delas é a fidelização, que nada mais é do que o relacionamento de longo prazo entre empresa e cliente. Ele é considerado fiel quando sempre volta à empresa por se sentir satisfeito com os produtos e serviços oferecidos. (BOGMANN, 2002) 


\section{Métodos e procedimentos de coleta e de análise de dados do estudo}

Este capítulo visa informar sobre as diversas decisões acerca da forma como este estudo foi realizado.

Está dividido em quatro seções que informam, respectivamente, sobre as etapas de coleta de dados e as fontes de informação selecionadas. Na sequência, informa-se sobre os processos e instrumentos de coleta de dados realizados em cada etapa, com respectivas justificativas e, por fim, sobre as formas escolhidas para tratar e analisar os dados coletados.

\subsection{Etapas da coleta de dados}

A metodologia escolhida para o estudo é a exploratória, que visa proporcionar maior familiaridade com o problema, sendo assim, o objetivo é aprimorar ideias ou descobertas de intuições (GIL,2002).

A técnica empregada é a qualitativa, por meio da qual o pesquisador busca desenvolver temas a partir da coleta de dados emergentes, podendo ser por meio de entrevistas com questões abertas (CRESWELI, 2007). Sendo assim, na pesquisa exploratória qualitativa constata-se que não há muita coisa escrita sobre o tema ou a população em análise, cabendo ao pesquisador ouvir os participantes, compreender e interpretar as ideias dos respondentes. De cunho subjetivo e profundo, a pesquisa qualitativa tem uma visão humanística do método, com isso, o pesquisador busca envolver os participantes na coleta de dados.

A primeira etapa foi realizada com a finalidade de selecionar somente mulheres da faixa etária que se insere na Geração $Y$ e que sejam consumidoras de produtos específicos para cabelos cacheados e crespos, para isso, foram disponibilizadas duas perguntas fechadas (filtro), abordando esses temas, uma vez que mulheres que não preenchessem esses dois critérios estariam fora do público alvo do estudo em questão.

A segunda etapa foi realizada por meio de uma entrevista qualitativa, já com o público alvo selecionado. 


\subsection{Fontes de informação selecionadas para a coleta de dados no estudo}

Sendo a metodologia escolhida a exploratória qualitativa, como já foi mencionado, a condução da coleta de dados pelo pesquisador foi no formato de entrevistas com perguntas abertas e semiestruturadas, pretendeu-se, assim, extrair visões e opiniões dos respondentes acerca do tema principal.

Foram realizadas 18 entrevistas com participantes já selecionadas, após a aplicação das perguntas do tipo filtro como dito no tópico anterior. Por conseguinte, nessa etapa, as entrevistadas selecionadas eram mulheres da Geração $Y$ da faixa etária de 21-34 anos, sendo obrigatoriamente consumidoras de produtos específicos para cabelos cacheados e crespos.

Visto a pandemia da Covid 19, para conseguir respondentes, foram necessárias entrevistas online via Whatsapp e por telefone com as pessoas que estavam dispostas a contribuir com o estudo, mas que não poderiam fazê-la presencialmente. Além disso, foi constatado que todas as entrevistadas são residentes à cidade do Rio de Janeiro.

\subsection{Procedimentos e instrumentos de coleta de dados utilizados no estudo}

Segundo Gil (2010), a técnica de entrevista é a mais flexível dentre todas do tipo investigação, podendo ser informal e focalizada, sendo esta última quando enfoca temas muito específicos. Na presente pesquisa, foi escolhido o tipo focalizado, dado que o pesquisador visa obter o máximo de informações sobre assuntos específicos do tema principal.

O pesquisador utiliza-se de notas manuscritas, gravação em áudio e vídeo para registrar as informações. (CRESWELL, 2007) Em entrevistas o pesquisador tem como controlar a linha de questionamento e absorver informações históricas do participante.

A entrevista parcialmente estruturada, com um roteiro por meio do qual o entrevistador elenca e explora pontos de interesse no decorrer da entrevista, visa captar as vertentes principais que buscam entender as múltiplas variáveis de um determinado assunto.

Os dados foram coletados por meio de entrevistas semiestruturadas online e por telefone através de um roteiro que se encontra em anexo para consulta. Grande parte das entrevistadas pelo Whatsapp preferiram, por uma questão de comodidade, fazer o registro escrito das respostas; poucas pessoas gravaram em 
áudio. Dessa forma, a entrevista com um roteiro de 14 perguntas preestabelecidas teve duração média de 20 minutos.

Cada entrevista foi iniciada com uma breve apresentação do tema da pesquisa. As duas primeiras perguntas eram as do tipo filtro, caso a pessoa atendesse os requisitos de idade e consumo de produtos para cacheadas e crespas, prosseguia para as perguntas abertas. Já nessa etapa, as perguntas iniciais abordavam os temas de motivação de uso e compra, quando necessário, para aprofundar um pouco os fatores motivacionais, indagava-se sobre benefícios e atributos no produto considerados para tomada de decisão; em seguida apresentou-se os seguintes tópicos de perguntas: fator primordial para compra; fontes de recomendações; campanhas que motivam a comprar, endosso de famosos na TV; atuação online das marcas; endosso das influenciadoras digitais; apelos na mensagem e, por fim, representatividade.

\subsection{Formas de tratamento e análise dos dados coletados para o estudo}

Extrair sentido dos dados do texto, prepará-los para análise, conduzir análises diferentes, refletir continuamente sobre os dados, fazer interpretações dos significados mais amplos dos dados são pontos que passam pela análise de dados (CRESWELL,2007).

O primeiro passo foi a organização e a preparação dos dados, com a transcrição das entrevistas que foram recolhidas via áudio do celular. Logo após seguiu-se a separação dos dados em diferentes temas, ou seja, categorizá-los por tipos de perguntas, como: motivação de consumo de produtos para cabelo, benefícios no uso de produtos; atributos dos produtos; tipos de recomendações que motivam a compra; influência da comunicação das marcas que motivam as consumidoras.

Com isso já pronto, o pesquisador olhou os dados e obteve um sentido mais amplo de todas as informações, para que depois, fosse feita uma interpretação e extração dos significados dos dados com base no referencial teórico do estudo, objetivo geral e específicos que foram pré-determinados.

\subsection{Limitações do Estudo}

Em relação às limitações do estudo, o risco há quando os entrevistados interpretam erroneamente as perguntas, o que pode levar a um comprometimento 
do resultado final da pesquisa. "As pessoas não são igualmente articuladas e perceptivas" (CRESWELL,2007, p.191).

Outro ponto crítico é a influência do pesquisador no decorrer da entrevista, dessa forma, a pesquisa pode acabar com uma visão limitada pelas experiências e características pessoais dele, deixando de lado o ponto de vista do público-alvo. "A presença do pesquisador pode enviesar as respostas". (CRESWELL,2007, p.191)

Por fim, os entrevistados podem considerar as perguntas longas e cansativas, com isso, as últimas perguntas podem não ter a mesma qualidade de respostas do que as primeiras. 


\section{Apresentação e análise dos resultados}

No presente capítulo haverá a apresentação e análise dos resultados oriundas das respostas das entrevistas, correlacionando-as entre si e com o referencial teórico dos capítulos anteriores, de forma a provocar discussões relevantes de suas implicações e significados. Essa análise está dividida em cinco seções, sendo elas: motivações das consumidoras e comportamento de compra, marcas nas mídias sociais, endosso das influenciadoras digitais, sustentabilidade e diversidade na mensagem e sugestões das consumidoras.

\subsection{Perfil das entrevistadas}

Foram entrevistadas 18 mulheres na faixa de etária de 21 a 34 anos, residentes à cidade do Rio de Janeiro. A entrevista não se utilizou de outros critérios como, profissão, classe social e etnia, pois o foco era compreender o ponto de vista geracional, das Millenials, e encontrar aspectos de paridade e diferença desse público em relação ao mercado de cosmético capilar para cacheadas e crespas.

\section{Tabela 1: Perfil das entrevistadas}

\begin{tabular}{|c|c|}
\hline Entrevistadas & Idade \\
\hline X1 & 29 \\
\hline X2 & 25 \\
\hline X3 & 23 \\
\hline X4 & 21 \\
\hline X5 & 31 \\
\hline X6 & 23 \\
\hline X7 & 34 \\
\hline X8 & 27 \\
\hline X9 & 29 \\
\hline X10 & 24 \\
\hline X11 & 26 \\
\hline X12 & 22 \\
\hline X13 & 25 \\
\hline X14 & 31 \\
\hline X15 & 30 \\
\hline X16 & 26 \\
\hline X17 & 28 \\
\hline X18 & 27 \\
\hline
\end{tabular}




\subsection{Resultado das entrevistas}

É importante salientar que alguns pontos de vista foram diferentes, mas ao todo, as entrevistas foram similares. A partir de uma visão holística das respostas foi possível chegar a algumas conclusões gerais que foram captadas em diversas falas.

Há uma procura por uma relação mais humanística e orgânica de consumo, seja escolhendo produtos mais naturais ou pela preferência de um relacionamento próximo com as fontes de informação ou mesmo com a marca, então, há um afastamento desse público de uma publicidade demasiada glamourizada. Conforme o próximo relato:

“...eu percebo que são mulheres de cabelo liso que fizeram algum tipo de babyliss sabe? Pra parecer que tem que ficar definido, não são mulheres que têm cabelos cacheados...a gente já percebia isso eu não gosto dessa coisa artificial, sabe? Não acho legal marcas que trabalham dessa forma, não sinto vontade de consumir esse tipo de produto." (X5, 31 anos)

Também é perceptível que elas buscam experiência de compra, testar o produto ou assistir alguém testando, pois mesmo um produto considerado bom pode ter um resultado satisfatório em um cabelo e em outro não. Quando isso vem especificado em uma propaganda ou embalagem, as chances são maiores de despertar a atenção das consumidoras, pôde-se concluir então que elas não se atraem por produtos capilares dos tipos genéricos, como: "creme de hidratação para todos os tipos de cabelo". Conforme o próximo relato:

"Gosto de saber como foi a experiência da pessoa com
aquele produto ou o que um profissional da área, que sabe
mais sobre essas coisas, sabe daquele produto em
diferentes tipos de cabelo. Claro que o que funciona pra
uma pessoa pode não funcionar para mim, mas acredito
que podem pelo menos guiar na hora de escolher." (X12,
22anos) "Hoje em dia bem mais representada, pois as marcas estão mais conscientes da necessidade de terem produtos específicos pra cabelos cacheados, o que até pouco tempo atrás não se tinha. " $(\mathrm{X}, 23$ anos)

Outra questão diz respeito à fidelização, pois a amostra entrevistada tem preferência em testar várias marcas e ficar constantemente mudando para que 0 cabelo não se acostume, além disso, as que disseram ter sim algumas marcas 
preferidas, enfatizaram empresas de nicho, com linha e comunicação direcionadas para esse público, como a Salon line Skala e Lola Cosmetics. Isso pode ser consequência da falta de representatividade percebida em marcas internacionais que atuam no Brasil. Conforme o próximo relato:

“...então se eu for entrar no site da L'Oréal Paris, no Instagram da L'Oréal Paris, vão ter várias mulheres brancas de cabelo liso, talvez um pouco mais ondulado, aí vai ter uma mulher branca, de cabelo preto, meio cacheado, raramente você vai encontrar a foto de uma mulher negra com um cabelo crespo. Então, eu começo a perguntar o quanto aquela marca, o quanto aquele produto foi feito realmente pensando em mim, de cabelo cacheado e o quanto aquele produto foi feito só pra suprir uma demanda e tentar vender para as pessoas, o quanto realmente a marca tá preocupada com o meu cabelo e o quanto a marca realmente investiu naquele produto." (X6, 23 anos)

\subsubsection{Motivações das consumidoras e comportamento de compra}

No início da entrevista foi abordada a questão sobre as motivações das cacheadas e crespas em relação à compra dos produtos. Como foi visto no item 3.4, a motivação se inicia com o despertar de uma necessidade ou desejo. As respostas obtidas da seguinte pergunta: "O que te motiva a comprar produtos para cabelos?", trouxe à tona algumas necessidades contempladas pelos níveis da Pirâmide de Maslow, tanto as dos níveis superiores como dos inferiores. Para Solomon (2016, p.22) "o mesmo produto ou atividade pode satisfazer várias necessidades diferentes".

Respostas que mostram motivações básicas de consumo apareceram em algumas entrevistas, do tipo "compro por necessidade", como pode ser visto a seguir:

\footnotetext{
"A necessidade mesmo. Meu cabelo é cacheado e eu compro produtos adequados para ele. Mas não me considero consumista com relação a isso. Compro mais quando acaba." (X10, 24 anos)

"Então, eu compro por necessidade mesmo, porque se eu não comprar cremes, o cabelo cacheado, ele não fica definido, né?" (X5, 31 anos)
}

Em diversas respostas é notável que as entrevistadas compram os cosméticos capilares visando melhorar a aparência, então, vaidade e autoestima 
foram questões levantadas. A preocupação acerca do aspecto visual dos cabelos caminha para questões mais emotivas e psicológicas, tanto como forma de obter alguma aceitação social como para sentir-se bem com si próprias, na Pirâmide de Maslow, respostas com esse cunho estariam alocadas na Necessidade de Estima. Kotler e Keller (2012) elencam como necessidades psicológicas que afetam o comportamento do consumidor as de reconhecimento, integração e estima. Nas duas respostas seguintes fica bem enfatizada a motivação por estima.

"O que motiva a comprar produtos para cabelo é a questão da aparência mesmo, a questão estética, quando eu utilizo cremes de cabelos ou às vezes um mousse de cabelo, ou uma gelatina, a aparência do meu cabelo fica mais saudável. Então, pela questão de estética mesmo acabo comprando produto de cabelo." (X6, 23 anos)

"A motivação é a partir dos cuidados para mantê-los naturais e bem tratados e também para melhorar minha autoestima." (X14, 31 anos)

Assim, o principal fator motivacional identificado na maioria das entrevistas tem ligação com os benefícios proporcionados pelos produtos nos cabelos, deixálos saudáveis é uma preocupação inerente as respondentes do estudo. Nesse sentido, nota-se um alto envolvimento com o produto, na medida em que elas percebem um risco ao adquiri-lo, pois, comprar um produto "ruim" pode significar ficar com uma aparência que não as agrade ou mesmo ter a saúde capilar comprometida. Blackwell, Miniard e Engel (2000) relacionam o envolvimento pessoal com fatores de produto, estes se tornam envolventes quando 0 consumidor capta algum risco na compra ou no uso, que inclui riscos psicológicos e de desempenho. Conforme os relatos a seguir:

"O que me motiva e o tipo de produto. Observo características como: tipo de cabelo, benefícios para cabelo (hidratação, reconstrução, nutrição) o cheiro e a embalagem." (X7, 34 anos)

"Como meu cabelo é cacheado existem alguns cuidados maiores que tenho que tomar para que ele fique saudável, então tenho que ir selecionando bem os produtos pra poder deixar meu cabelo o mais saudável possível. Tento cuidar o máximo possível então compro produtos que acho que podem ajudar." (X12, 22 anos)

Para que se consiga atingir os benefícios almejados de tratamento e manutenção dos fios, percebe-se que as consumidoras são cautelosas e 
exigentes quanto à qualidade e composição dos produtos. Composições com ingredientes desenvolvidos para as técnicas no poo e low poo (que usa nada ou pouquíssimo sulfato) e também os que são a base de óleos, são exemplos das demandas das respondentes percebidas nas respostas, a maioria menciona que buscam resultados satisfatórios nos cabelos. Conforme os relatos a seguir:

\begin{abstract}
"Do produto quando eu vou comprar, eu sempre busco saber sobre os ingredientes, porque eu tô utilizando a técnica de no poo no cabelo. Então, existem ingredientes que alguns produtos têm, que não são liberados pra essa técnica. Então, eu sempre dou uma olhada, busco se é considerado liberado, que eu posso usar o que eu não posso em relação ao produto, assim, olhando também a questão do cheiro, impacta um pouco, mas não muito, acho que a questão dos ingredientes hoje em dia é um dos pontos mais importantes." (X6, 23 anos)
\end{abstract}

"Os benefícios que eu espero é que o resultado que o produto diz trazer para o cabelo, realmente aconteça no meu." (X17, 28 anos)

A questão seguinte foi um questionamento sobre os fatores efetivos que são considerados pra tomada de decisão de compra da consumidora. Blackwell, Miniard e Engel (2000) argumentam que algumas variáveis moldam a tomada de decisão do consumidor e que isso engloba diversos fatores e determinantes, sendo categorizados em processos psicológicos, influências ambientais e diferenças individuais. Dois fatores foram citados em todas as entrevistas: preço e qualidade. Para Aaker (1998) a qualidade percebida de um produto é um fator fundamental, transformando-se na razão de compra no processo decisório, isso ocorre quando o cliente tem conhecimento sobre a superioridade de um produto em relação às alternativas. A sensibilidade aos preços e à qualidade denota um perfil semelhante no grupo entrevistado, porém outros pontos também foram levantados pelas respondentes, em menor escala, nessa pergunta, como: marca, facilidade de encontrar, atendimento, resultado em outros cabelos e composição dos produtos. A seguir duas entrevistadas falam sobre a tomada de decisão de compra de um produto. Conforme as falas a seguir:

"Qualidade e preço. Ter um produto que garanta um resultado, mas seja acessível é o que me faz decidir por um ou outro." (X13, 25 anos) 
"Preço, qualidade e componentes utilizados. Como faço Low Poo, só consumo produtos sem silicones, derivados de petróleo e componentes agressivos. Não me importo muito com marca." (X16, 26 anos)

A próxima pergunta tinha como objetivo identificar as fontes de informações que as consumidoras mais utilizam ao pesquisar por um determinado produto, bem como entender as motivações de tais escolhas. Em primeiro lugar, foi citado por quase todas as entrevistadas o uso das redes sociais, principalmente 0 YouTube e Instagram, além disso, também assinalaram o uso do Google como fonte de pesquisa; de cabelereiros especializados em cacheadas e crespas; indicação de amigas; indicação das vendedoras de lojas especializadas e descrição dos ingredientes e maneiras de uso no rótulo das embalagens. Em relação às motivações, em todas as respostas foi possível perceber que as entrevistadas são influenciadas a comprar quando veem o uso do produto em cabelos similares aos seus, por meio das resenhas de blogueiras cacheadas e crespas, ou de pessoas comuns que usam o produto no dia a dia e, por fim, ao consultar informações passadas por profissionais (que estudam fórmulas e produtos). A seguir três relatos das entrevistadas sobre a influência das fontes na tomada de decisão.

\footnotetext{
"Troco informações com conhecidas cacheadas, pesquiso a avaliação do produto na internet e me baseio em influencers cacheadas. Confio nos gostos das minhas conhecidas e a avaliação positiva de um grande número de pessoas me leva a acreditar que a chance de eu gostar também são grandes." (X4, 21 anos)

"Instagram, blogueiras negras, sites, vídeos no YouTube. / Questão de ser acessível e representatividade." (X14, 31 anos)

"Internet, em grupos específicos sobre o assunto. / Prefiro dar mais prioridade a consumir coisas indicadas por gente "como eu", do que por outras fontes que provavelmente ganham para indicar aquele produto e falar bem dele." (X16, 26 anos)
}

Como percebe-se neste último relato, foi identificado em muitas entrevistas que há um receio por parte das consumidoras a respeito das indicações feitas por pessoas que foram pagas para fazer publicidade no Instagram ou resenha no Youtube; por exemplo, as entrevistadas mencionaram que as influenciadoras digitais contratadas podem não ser genuínas ao divulgar produtos de determinadas marcas. 


\subsubsection{Marcas nas Mídias Sociais}

No item 3.3.3, foi visto a importância das mídias digitais na estratégia de comunicação das marcas, notoriamente das redes sociais, que são um instrumento poderoso de busca de informação das consumidoras. O público alvo da pesquisa são mulheres da Geração $Y$, reconhecidas por serem muito conectadas e usuárias assíduas das redes. Para Kotler e Keller (2012, p.589) "As mídias sociais são um meio para os consumidores compartilharem textos, imagens e arquivos de áudio e vídeo entre si e com as empresas. As mídias sociais dão às empresas voz e presença pública na Web, além de reforçarem outras atividades de comunicação." Ainda para o mesmo autor, "As empresas podem alimentar os consumidores com informações e atualizações por meio de postagens em blogs e outras postagens de conteúdo, dar suporte a comunidades on-line e criar seus próprios assuntos no dinâmico mundo da Internet." (KOTLER; KELLER, p.13).

Ao perguntar para as entrevistadas sobre a opinião delas a respeito da interatividade das marcas com as consumidoras nas redes sociais, buscava-se entender a percepção delas sobre essa estratégia já adotada pelas empresas de cacheadas e crespas há algum tempo. O comportamento de compra do consumidor é influenciado pela percepção que os consumidores têm de alguma situação. A percepção depende tanto de estímulos ambientais quanto das condições internas do indivíduo, e é definido como o processo pelo qual o consumidor seleciona, organiza e interpreta as informações recebidas de forma a criar uma imagem significativa do mundo. (KOTLER; KELLER, 2012)

Em suma, todas as entrevistadas enxergam como positiva e assertiva a interação marca-consumidor nas redes sociais, pois, segundo as respostas coletadas, diferentemente de outros meios, esse tipo de mídia entende mais a individualidade de cada um, assim, se cria uma conexão mais profunda e duradoura. As empresas mantem uma rotina de interatividade para estabelecer um elo com os clientes de modo a torná-los fiéis a marca futuramente. A respondente a seguir fala sobre a importância dos feedbacks nas redes.

"Hoje em dia eu vejo que essa interatividade acontece de forma mais abrangente do que alguns anos atrás, hoje em dia as empresas fazem produtos olhando a individualidade de cada grupo e não algo para a massa, coisa que acontecia antigamente, então eu vejo que eles estão mais 
interessados em agradar o nicho deles, ouvindo opiniões e críticas." (X17, 28 anos)

Logo em seguida, houve um questionamento a respeito das redes sociais das marcas que as entrevistadas seguem, bem como a frequência e suas motivações. A rede social mais seguida é o Instagram e com menos frequência o Facebook, além disso, duas entrevistadas disseram não seguir nenhuma marca, contudo, têm o costume de entrar esporadicamente nos perfis para acompanhar alguma novidade. A maioria das entrevistadas não soube precisar a frequência, e duas pessoas disseram que acessam os perfis das marcas todos os dias; os motivos mencionados para esse acompanhamento são: verificar lançamentos; tirar dúvidas sobre algum produto em específico; interagir com as marcas ou influencers no privado; se informar sobre promoções, maneiras de uso dos produtos e identificar tendências. A entrevistada a seguir diz sobre os motivos de acompanhar as marcas nas redes."

“...Instagram, não tenho uma frequência. Para vê se tem produtos novos. Ou novas maneiras de uso de produtos antigos." (X1, 29 anos)

O embate meio digital versus meio de massa é importante para saber se há uma real efetividade em algumas estratégias adotadas pelas empresas. Com esse intuito foi indagado às respondentes se elas são influenciadas a comprar quando veem um comercial de TV no qual aparece alguma celebridade. Grande parte das entrevistadas disseram não ser influenciadas atualmente por comerciais na televisão, justificando que não há credibilidade nas divulgações nesse meio, contudo, algumas levam em conspiração o endosso de pessoas famosas ou não que identificam ter os cabelos semelhantes aos seus. Cinco entrevistadas disseram ser sugestionadas por celebridades que aparecem em comerciais de TV.

"Sim, Thais Araújo e uma mini série (subúrbia) eu comecei
a achar o cabelo natural a coisa mais linda." (X1,29 anos)
"Já fui, mas hoje sou mais influenciada por pessoas
(famosas ou não) que tenham cabelos parecidos com os
meus." (X13, 25 anos)
"Não, eu não acredito muito bem nesses cabelos de
modelos nos comerciais de TV. Principalmente de
celebridades." (X11, 26 anos)

Sendo assim, o resultado dessa comparação é o reflexo do poder atual das mídias sociais na estratégia de comunicação das marcas, ao passo que, os 
veículos importantes como a TV cada vez mais perdem espaço no que tange à influência de compra. No caso do estudo, tal meio se mostra pouco efetivo em conseguir atenção e uma mudança de atitude das consumidoras cacheadas e crespas da Geração Y.

\subsubsection{Endosso das Influenciadoras Digitais}

Como visto no capítulo 3.3.1, as influenciadoras digitais têm um papel importante na estratégia de comunicação das marcas. A escolha desse tipo de endosso pelas empresas acontece, pois há uma inclinação na atualidade de que se haja um relacionamento mais humanizado entre marca e consumidor e não mais puramente comercial. E para que isso seja concretizado, as influencers atuam como elo nesse diálogo, em razão de que são referências em algum assunto ou produto de interesse dos internautas, conseguindo despertar sua atenção, confiança e influenciá-los em suas tomadas de decisão de compra. (LINO,2016)

Houve dois questionamentos sobre o endosso das influenciadoras digitais como forma de comunicar marca e produto. O primeiro buscou entender a percepção das consumidoras em relação a utilização da influenciadora para recomendação de produtos, sendo assim, seis respostas foram positivas a respeito dessa estratégia, fatores positivos, como o grande alcance e engajamento que tais fontes proporcionam foram levantados. Entretanto, grande parte das entrevistadas mostraram um certo receio quanto a esse tipo de endosso, assim como já foi visto em um tópico anterior; dado que, para as respondentes, algumas influenciadoras não passam verdade em sua mensagem, ou seja, há uma percepção de que a divulgação ocorre unicamente em troca de remuneração. Algumas respondentes disseram que há uma maior confiabilidade no produto quando é sabido que a influenciadora não foi paga para falar de alguma marca específica. O segundo questionamento teve como resultado o reflexo da primeira pergunta; ao indagar sobre a frequência de compras após assistir uma recomendação feita por uma influenciadora digital, a maioria respondeu "não" ou "raramente". A seguir duas respostas com visões completamente diferentes sobre as influenciadoras, uma positiva e outra negativa sobre essa estratégia.

"Ótimo! Porque cada influenciadora tem seu público específico e se eu sigo alguma é porque me identifico com ela, e as influenciadores acabam trazendo uma proximidade por mostrar o seu dia a dia, então eu creio 
que o fato de falar a mesma "língua "é um ponto super positivo para as marcas, pois atingi o público certo. /// Quase sempre! Toda vez que vai acabando meus produtos eu sempre procuro o que elas estão falando e quero experimentar." (X17, 28 anos)

"Estratégia de marketing, apenas. Formas de se fazer dinheiro, pagando uma pessoa famosa pra falar bem daquele produto. Dificilmente consumo esse tipo de conteúdo, pois não sinto muita veracidade. I/I Nunca." (X16, 26 anos)

\title{
5.2.4.Sustentabilidade e Diversidade na Mensagem
}

A mensagem que tem apelo à sustentabilidade e diversidade é uma estratégia em voga na comunicação das marcas para cabelos cacheados e crespos, como visto no tópico 3.3.2. Então as perguntas que abordavam tais temas visavam entender a percepção das consumidoras em relação a isso.

Sacchitiello (2017), traz a estratégia de comunicação focada na diversidade das marcas Seda e Dove, conforme relata o gerente de marketing Diego Guareschi.

\begin{abstract}
"buscamos novamente um grupo de influenciadoras que representasse toda a beleza e diversidade dos cachos e crespos: loiras, ruivas, morenas, com cachos mais abertos, crespas. Elas darão dicas, formas e técnicas diferentes de cuidar de seus fios".
\end{abstract}

O relato anterior corrobora com o resultado obtido nas entrevistas, já que, quando perguntadas a respeito do uso da diversidade na comunicação das marcas, todas as respondentes se mostraram favoráveis a esse tipo de apelo na mensagem, elencando pontos que elas percebem na comunicação das empresas, como: diversidade de público/corpo; diversidade de cabelos nas propagandas e diversidade de cor. A seguir o relato de algumas entrevistadas:

\footnotetext{
"sobre a diversidade acho importante para contribuir com a quebra de um estereótipo padrão, podendo fornecer produtos que atendam às necessidades individuais de cada cabelo (que são várias)." (X1, 29 anos)

"Cada vez mais necessário. Penso que todas as marcas deveriam ser pra todas as pessoas sem distinção e, é importante que todas elas possam se sentir representadas nas propagandas e que, cada vez mais os produtos correspondam a suas expectativas, pluralidade e seus ideais." (X16, 26 anos)
} 
De acordo com um estudo da universidade de Yale, dos Estados Unidos, as mulheres são as que mais são ligadas às mensagens que diz respeito ao meio ambiente, e suas atitudes mostram isso, pois: produzem menos lixo, reciclam mais, comem menos carne e são mais propensas a comprar produtos $100 \%$ ecológicos e sustentáveis, isso se justifica pois elas são mais receosas sobre o futuro das próximas gerações. (VILELA, 2021). Nesse aspecto, novamente, todas as entrevistadas enxergam como sendo um ponto positivo e importante na mensagem da marca esse tipo de tema. Algumas respondentes disseram que ficam mais motivadas a comprar quando conseguem identificar que a marca tem selos vegano e cruelty free.

"Marcas veganas/cruelty-free deveriam ser mais valorizadas e difundidas." (X13, 25 anos)

Uma pergunta que foi anterior a essa supracitada, questionava as respondentes que campanhas ou ações da marca já as motivaram a comprar, e foi identificado que diversas respostas batiam com as questões de diversidade, produtos veganos, aceitação e identificação visual com a endossante, criando assim um alto envolvimento com mensagem. Visto isso, conclui-se que a abordagem de tais temas na comunicação das marcas tende a criar empatia e conexão com o público, podendo transformar-se em uma ação positiva do consumidor, tais como: compra de produtos, divulgação para amigos e familiares, geração de comentários positivos na internet, dentre outros.

"Costumo ser mais influenciada por campanhas que tenhas pessoas negras e reais, não conhecidos da mídia. Acho que me aproxima mais do produto." (X4, 21 anos)

"Colocarem mulheres negras com cabelos crespos de todos os tipos, inclusive, o meu que é 4c." (X14, 31 anos) "Olha não sei qual foi a campanha, mas qualquer campanha que fale de aceitação, de assumir o volume e deixar o cabelo livre e solto me chama muita atenção." (X17, 28 anos)

"Usar cabelos reais para mostrar o resultado do produto e mostrar que a marca não testa em animais/é vegana." (X23, 25 anos)

Como discutido na pesquisa, antes, as cacheadas e crespas não se sentiam representadas pelas empresas pois não haviam produtos específicos para o seu tipo capilar e, muito menos, uma comunicação voltada a esse público. Visto isso, 
a última pergunta pretendeu-se descobrir o quanto as entrevistadas se sentem representadas atualmente pelas marcas. Percebe-se que o resultado da estratégia de comunicação das marcas nos últimos anos foi positivo, visto que $90 \%$ das entrevistadas disseram se sentir bem representadas.

"Hoje em dia eu me sinto representada, pois eu abro as redes sociais e vejo pessoas com o mesmo tipo de cabelo que o meu, vou nos mercados e farmácias e vejo produtos para o meu cabelo, coisa que antigamente não existia, além de só ter produtos para conter o volume do meu cabelo, como se volume fosse um problema a maioria das celebridades eram brancas do cabelo liso. Já hoje eu consigo olhar tanto nas mídias online como off-line mulheres com que eu me identifico." (X17, 28 anos)

"Numa escala de zero a 10, 10. Pois hoje é possível encontrar todos os recursos necessários, em diversas marcas, com diversos preços, em todo tipo de farmácia. 0 cabelo cacheado/crespo hoje, diferente de algum tempo atrás, possui produtos que atendem positivamente suas características." (X13, 25 anos)

\subsubsection{Sugestões das Consumidoras}

Quando perguntadas sobre quais outros temas as entrevistadas gostariam de ver na publicidade das marcas, elas deram as seguintes opiniões:

"Clientes que realmente usam os produtos. Experiência de clientes de verdades." (X15, 30 anos)

“...a maioria das pessoas que compram produtos pra cabelo são as mulheres, mas tem muito homem de cabelo cacheado também...Isso não se vê muito em propaganda, em comercial. Então, acho que eles poderiam melhorar isso. Eu sei, por exemplo, que a Skala, faz isso, usam os influenciadores homens. Mas, por exemplo, Lola não usa, inclusive, chamam as clientes de "loletes". Não foi pensada muito nessa questão dos homens. $E$ acho que tem muito ainda 0 que avançar também nessa questão de diversidade...." (X2, 25 anos)

"Produtos para crianças, homens e cabelos quimicamente tratados." (X7, 34 anos)

"Além de diversidade de corpos, também prezo pela diversidade de gênero e cor. Além disso, gostaria de ver mais pessoas PCD's e com doenças como o vitiligo, por exemplo." (X10, 24 anos) 
"Gostaria que eles deixassem mais claro sobre a importância de se ter produtos veganos/cruelty-free e fazer disso uma ferramenta que atraísse mais compradores." (X13, 25 anos)

"Colocar homens também cuidando do cabelo." (X14, 31 anos)

“...gosto de ver o produto, se for um produto que mostra que ele realmente tenha qualidade e que ele realmente traz um efeito no cabelo cacheado, porque cabelo cacheado demanda mais cuidados, às vezes do que outros tipos de fios. Então, eu gosto de ver nas campanhas que eles ressaltem esse tipo de qualidade e atributo." (X18, 27 anos)

Com isso, pode-se dizer que ao longo dos anos as estratégias de comunicação das marcas evoluíram juntamente com a pesquisa e desenvolvimento de novos produtos específicos para cabelos cacheados e crespos, visto que na sua totalidade se mostram eficazes. 


\section{Conclusões e recomendações para novos estudos}

A presente pesquisa teve como objetivo analisar dois eixos que se interrelacionam, que são: as motivações de uso e compra do público feminino da Geração $Y$ e as tendências de estratégia de comunicação que as marcas adotam para influenciar e se aproximar dessas consumidoras. O consumo de produtos específicos para cabelos cacheados e crespos 'se mostra crescente, e a entrada das marcas nesse nicho foi uma resposta às mulheres que ficavam à margem de um mercado capilar voltado quase que exclusivamente para as "lisas", isso reflete em um impacto econômico e social, com isso, o estudo desse público passa a ter um valor importante. Para isso foram realizadas 18 entrevistas em profundidade com mulheres cariocas da Geração $Y$ consumidoras de produtos para cabelos cacheados e crespos.

A ascensão do nicho cacheado e crespo é um fenômeno recente, mas que provocou mudanças profundas na sociedade como um todo. Como visto na introdução e referencial teórico do estudo, o impacto desse acontecimento teve desdobramentos importantes na indústria cosmética, no mercado publicitário e em redes de relacionamentos, porém, a mudança mais significativa diz respeito ao interior de cada mulher que teve a autoestima renovada, que se sente representada e que está motivada a ajudar outras pessoas no processo de valorização dos fios naturais.

Em relação às motivações de uso e compra, algumas ficaram evidenciadas, como: autoestima, resultado visual e saúde capilar, que são aspectos essenciais para esse público e, para que sejam alcançados, cada vez mais há uma busca por ingredientes orgânicos e específicos. No processo de decisão de compra os fatores determinantes são qualidade e preço, considerando como fontes de recomendações principais: as redes sociais, profissionais especializados e amigos/familiares. Contudo, uma tendência identificada consiste na experimentação do produto, como é de costume no segmento de maquiagem. Dessa forma, a compra compulsiva pode ser afetada, principalmente em pontos de vendas que não disponibilizam fontes de experimentação de produtos para as clientes. No quesito expectativa versus realidade, muitas respondentes disseram 
que têm a necessidade de perceber que o produto cumpra com o que foi prometido na embalagem.

Verificou-se que essas consumidoras são críticas em relação à comunicação das marcas, pois não aceitam qualquer tipo de endossante, meio e mensagem. Quanto mais uma campanha ou ação se mostra artificial, menos as espectadoras serão influenciadas a comprar determinado produto. Nesse aspecto, entram marcas que utilizam garotas-propaganda muito distantes da real aparência do público-alvo. Em relação às influenciadoras digitas, o problema consiste no vínculo comercial que essas endossantes têm com as empresas, já que, as entrevistadas disseram que não confiam na sugestão de alguém que está sendo paga para isso. Entretanto, muitas respondentes afirmaram que utilizam como principal meio de informação os canais no YouTube de blogueiras que não são patrocinadas por marcas, pois, por meio desse veículo, elas têm contato com uma endossante com cabelos que se assemelham aos delas, servindo assim como fonte de inspiração.

A atuação das marcas nas redes sociais se mostra eficaz e relevante para grande parte das entrevistadas, pois fica evidente que as empresas de nicho para cacheadas e crespas se empenham cada vez mais em criar vínculos estreitos com as clientes. Tal fato, permite a aproximação de uma comunidade virtual. Tendo em vista isso, clientes, influencers, marcas e demais públicos de interesse formam uma rede para compartilhamento de experiências, ideias, críticas, demandas e apoio, o que proporciona para aos profissionais de marketing uma poderosa fonte de informação. Em contrapartida, veículos de massa como a TV não são tão persuasivas na comunicação direcionada às cacheadas e crespas.

Por fim, os estímulos de marketing que possuem apelos sustentáveis e de diversidade buscam atingir o lado emotivo das clientes. Conscientizar, motivar e ir muito além do produto, é o que essa estratégia pretende, e, esses objetivos estão sendo atingidos, uma vez que as respondentes consideraram ser extremamente importantes campanhas e ações com tais temáticas, além do mais, algumas consumidoras utilizam esse tipo de comunicação como pré-requisito para avaliação das alternativas das marcas. 


\subsection{Recomendações para no os estudos}

Para futuros estudos, seria interessante um olhar sobre a classe social, já que os produtos capilares variam muito de preços. À vista disso, poderia ser feita uma pesquisa comparativa no processo de decisão de compra entre mulheres de baixa renda e classe média.

Outro tipo de estudo seria sobre a percepção das consumidoras em relação a atuação de determinada marca, como a Skala, por exemplo, assim, poderiam ser identificadas as melhores estratégias adotadas pela organização e como elas impactam no comportamento do consumidor.

\subsection{Sugestões}

Este tópico pretende colaborar com ideias para as estratégias de marca que visam atender o público feminino cacheado e crespo.

Como foi relatado durante a pesquisa, grande parte das entrevistadas se motivam a comprar quando de alguma forma conseguem ter detalhes sobre os produtos ou formas de experimentá-los, alguns relatos diziam ter dificuldade de encontrar informações de algumas marcas no ponto de vendas, então, a intensificação de uso de promotores nesses locais pode ser um diferencial.

Outra questão 'diz respeito à comunicação de produtos "verdes", que apesar de mais conhecidos atualmente, ainda são pouco divulgados nos meios de comunicação; uma divulgação mais intensiva em campanhas e ações seria relevante tanto para conscientização de causas sustentáveis com novas clientes, como para o fortalecimento da imagem da marca junto às consumidoras mais sensíveis ao tema, podendo gerar um maior engajamento.

E por último, vem a questão das influenciadoras pagas, como resultado da entrevista, a visão das consumidoras não está sendo favorável em relação a esse tipo de endosso. Provavelmente, por uma incongruência entre a identidade da marca e das influenciadoras ou na forma de transmissão da mensagem, é necessário uma revisão dessa estratégia de comunicação; por exemplo, muitas

marcas apostam em grandes Youtubers, por elas já terem um expressivo engajamento, porém, as micro influencers costumam ter realmente uma relação mais próxima com as internautas, trazendo mais confiabilidade e segurança em suas recomendações, então seria interessante que as empresas utilizassem mais esse tipo de endosso, fazendo uma pesquisa com as que são referência para 
cacheadas e crespas e, com isso, um planejamento de comunicação visando divulgar o produto de forma mais orgânica e natural. 


\section{Referências Bibliográficas}

ANDRADE, J. A fama como passaporte para a atenção: reflexões sobre o uso de celebridades na comunicação de marketing global. Internext - Revista Eletrônica de Negócios Internacionais, São Paulo, v. 3, n. 1, p. 16-38, jan./jun. 2008.

AAKER, D. A. Marca: Brand Equity Gerenciando o valor da marca. 5. ed. São Paulo: Negócio Editora, 1998.

Almeida, H. Cosméticos - Setor mantém vendas crescentes - Perspectivas 2020. Química.com.br, São Paulo, 22 de mar. de 2020. Disponível em: $<$ https://www.quimica.com.br/cosmeticos-setor-mantem-vendas-crescentesperspectivas-2020/\#: :text=Cosméticos\%20\%20Apesar\%20da\%20crise\%20econômica, Perfumaria\%20e\%20Cosméticos\%20(Abihpec)>. Acesso em: 10 de dezembro de 2020.

AMARO, K. Deva Curl - Conheça a Trajetória da Marca que Revolucionou o Conceito sobre Cabelos Cacheados. Patricinha esperta, 2012?. Disponível em:< https://patricinhaesperta.com.br/cabelos/deva-curl-conheca-a-tragetoria-damarca-que-revolucionou-o-conceito-sobre-cabelos-cacheados> Acesso em: 05 de maio de 2021.

AMBIENTEBRASIL. Nielsen: Produtos sustentáveis de higiene e beleza crescem em consumo e aumentam participação no faturamento da indústria. 13 out. 2019. Disponível em: <https://noticias.ambientebrasil.com.br/divulgacao/2019/10/13/154604-nielsenprodutos-sustentaveis-de-higiene-beleza-crescem-em-consumo-e-aumentamparticipacao-no-faturamento-da-industria.html>. Acesso em: 12 de maio de 2021.

Associação Brasileira das Indústrias de Higiene Pessoal, Perfumaria e Cosméticos (ABIHPEC) e Agência Brasileira de Desenvolvimento Industrial (ABDI); IV Caderno de Tendências: Higiene Pessoal, Perfumaria e Cosméticos 2019/2020; Ano 4/ no 4; 2018.

AUSTIN, B. A história do "pente quente" para cabelos. EHOW, 21 nov. 2017. Disponível em:< https://www.ehow.com.br/historia-pente-quente-cabelossobre_80654/>. Acesso em 20 de maio.

BENTIVEGNA, F. J. Fatores de impacto no sucesso do marketing boca a Boca. Revista de Administração de Empresas/FGV-EAESP, v. 42, n.1, p. 79-87, 2002.

BLACKWELL, R.; MINIARD, P.; ENGEL, J. Comportamento do consumidor. 8. ed. Rio de Janeiro: Cengage Learning, 2000. 
BOGMAN, I. M. Marketing de relacionamento: estratégias de fidelização e suas implicações financeiras. São Paulo: Livraria Nobel,2002.

BORGES, C. N. A nova comunicação e o advento dos digitais influencers: pesquisa realizada sobre blogueiras de moda. XVIII Congresso de Ciências da Comunicação na Região Centro-Oeste.Goiânia: Intercom - Sociedade Brasileira de Estudos Interdisciplinares da Comunicação, 2016.

BLUMARE. O Ontem | Como eram os alisamentos. São Paulo, 21 de fev. de 2018. Disponível em:<https://blumarepro.com.br/especial-alisamento-revista-cabelosblumare-pro/> Acesso em: 10 de maio de 2021.

BRAGA, B.J. A mulher negra nas embalagens de cosméticos para cabelos crespos e cacheados. Vitória, 2020. 171 p. Dissertação (Mestrado em Comunicação e Territorialidades) - Centro de Artes: Universidade Federal do Espírito Santo.

BRAZILBEAUTYNEWS. Setor brasileiro de cosméticos e higiene pessoalfecha2020 com alta de 5,8\%. Disponível em:<

https://www.brazilbeautynews.com/setor-brasileiro-de-cosmeticos-e-higienepessoal,3948>. Acesso em: 10 maio de 2021.

BUZZLEAD. 39 Estatísticas Que Comprovam Que O Marketing Boca A Boca Funciona Para Qualquer Negócio. 5 dez. 2017. Disponível em:< https://buzzlead.com.br/39-estatisticas-marketing-boca-a-boca/> Acesso em: 05 de maio de 2021.

CAETANO, R. A força da Geração Y. Isto é Dinheiro, 09 mar. 2015. Disponível em:<https://www.istoedinheiro.com.br/a-forca-da-geracao-y/>. Acesso em: 20 de maio de 2021.

CHURCHILL, G. A.; PETER, J. Paul. Marketing: criando valor para os clientes. Saraiva, 2 ed. São Paulo: Saraiva, 2010.

CRESWELL, J. W. Projeto de Pesquisa: Métodos qualitativo, quantitativo e misto. Porto Alegre. Editora: Artmed. 2ª Edição. 2007.

DINO. Brasil, terceiro mercado do mundo em produtos capilares. Estadão, Brasil, 24 jul. 2019.2 Disponível em: <http://patrocinados.estadao.com.br/medialab/projeto-navas/release-geral-brasilterceiro-maior-mercado-do-mundo-em-produtos-capilares/>. Acesso em 23 de maio de 2021.

DINO. A importância do Marketing Digital nos dias de hoje. 10 fev. 2020. Disponível em: < http://noticias.dino.com.br/a-importancia-do-marketing-digitalnos-dias-de-hoje-228782/>. Acesso em: 12 de maio de 2021.

DINO. Marketing Digital é utilizado pelos empresários como estratégia no setor on-line para embarcar um maior público em redes sociais. Monitor de Mercado, 10 mai. 2020. Disponível em: <https://monitordomercado.com.br/dinonews/4688>. Acesso em: 2 de maio de 2021. 
EXTRA. Atrizes com o cabelo crespo viram embaixadoras de marcas de beleza. 20 ago. 2017. Disponível em: <Veja dicas para cachoshttps://extra.globo.com/mulher/cabelos/atrizes-com-cabelo-crespo-viramembaixadoras-de-marcas-de-beleza-veja-dicas-para-cachos-21723300.html>. Acesso em 20 de maio.

FRANQUILINO, E. A volta dos cachos. Revista de Negócios da Indústria de Beleza, ano 12, n.36, 2017.

GIAMPA, S. Precisamos falar sobre produtos que 'se dizem' para cachos. 24. ago. 2016. Disponível em: <lhttp://cachosefatos.com.br/2016/08/produtos-paracachos-x-produtos-que-se-dizem-para-cachos.html> Acesso em: 05 de maio de 2021.

GOOGLE. Dossiê BrandLab: A Revolução dos Cachos. São Paulo: 2017. Disponível em:<https://www.thinkwithgoogle.com/intl/pt-br/estrategias-demarketing/video/revolucao-dos-cachos/>. Acesso em 25 de maio de 2021.

GABRIEL, M. Marketing na Era Digital: Conceitos, Plataformas e Estratégias. São Paulo, Novatec, 2010.

GALEMBECK, F.; CSORDAS, Y. Cosméticos: a química da beleza. [2009?]. Disponível em:< https://fisiosale.com.br/assets/9no\%C3\%A7\%C3\%B5es-decosmetologia-2210.pdf>. Acesso em: 01/06/2021.

GIL, A. C. Como elaborar projetos de pesquisa. 5. ed. São Paulo: Atlas, 2010.

KOTLER, P.; KELLER, K. L. Administração de marketing. 14. ed. São Paulo: Pearson Education do Brasil, 2012.

LINO, A. F. M. Influenciadoras digitais: uma análise da atuação das Embaixadoras de cosméticos para cabelos cacheados e crespos no Instagram. João Pessoa, 2018. 54 p. TCC (Graduação em Relações Públicas) Departamento de Comunicação: Universidade Federal da Paraíba.

LIPKIN, A. N.; April, P. A geração y no trabalho: como lidar com a força de trabalho que influenciará definitivamente a cultura da sua empresa. Rio deJaneiro: ed. Elsevier, 2010

MERCADO\&CONSUMO. Cresce o consumo de produtos sustentáveis de higiene e beleza. $10 \quad$ out. 2019 . Disponível em:<https://mercadoeconsumo.com.br/2019/10/10/cresce-o-consumo-deprodutos-sustentaveis-de-higiene-e-beleza/>. Acesso em 20 de maio.

MARQUES, T. Você sabe a diferença entre marcas veganas e cruelty free? Confira as opções!. Purebreak. 26 abr. Disponível em: <2021.https://www.purebreak.com.br/noticias/marcas-veganas-x-cruelty-freeentenda-a-diferenca-e-veja-opcoes/98070 >. Disponível em: 12 de maio de 2021.

MORAES, L. Mercado de cabelos cresce e movimenta $R \$ 8$ bi no Brasil. Kantarworldpanel, $01 \quad$ nov. $2018 . \quad$ Disponível em:<https://www.kantarworldpanel.com/br/Releases/Mercado-de-cabelos- 
cresce-e-movimenta-R-8-bi-no-Brasil>. Acesso em: 20 de maio.

NEIL, P. Mídia Digital: Entenda o Que é, os Tipos e Como Usar no Seu Negócio.Neil Patel.com, 2021? Disponível em:< https://neilpatel.com/br/blog/midia-

digital/\#: :text=Anúncios\%20pagos\%20no\%20Facebook\%20Ads,Mídia\%20paga $<$. Acesso em: 2 de maio de 2021.

NEGOCIOSSC. O surpreendente mercado de beleza no Brasil e seu público. Disponível em:<https://negociossc.com.br/blog/o-surpreendente-mercado-debeleza-no-brasil-e-seu-publico/>. Acesso em: 21 de maio de 2021.

OLIVEIRA, A, S. Trançando cabelo, identidade, estigma e consumo: um estudo sobre as maneiras de consumir relacionadas à manipulação capilar de mulheres de cabelos crespos e cacheados a partir da teoria da prática. Belo Horizonte, 2019. 299 p. Dissertação (Mestrado em Administração) - Centro de Pós Graduação e Pesquisas em Administração: Universidade Federal de Minas Gerais.

PINHEIRO, A. V. Cachos: a nova onda das marcas: um estudo sobre aidentificação de mulheres crespas e cacheadas com a publicidade atual. Goiânia, 2018. 97 p. TCC (Graduação em Comunicação Social - Publicidade e Propaganda) - Departamento de Comunicação: Universidade Federal de Goiás.

QUINTÃO, A. M. P. O que ela tem na cabeça: um estudo sobre o cabelo como performance identitária. Niterói, 2013. 197 p. Dissertação (Mestrado em Antropologia) - Departamento de Antropologia: Universidade Federal Fluminense.

QUINTILIANO, R. Você conhece o método Curly Girl? Revista Raça, 18 jul. 2017. Disponível em: <https://revistaraca.com.br/voce-conhece-o-metodo-curly-girl/> Acesso em: 2 de maio de 2021

Sacchitiello, B. Cabelos lisos já são minoria em comerciais de TV. Meio\&Mensagem, São Paulo, 13 de ago. de 2018. Disponível em: <https://www.meioemensagem.com.br/home/comunicacao/2018/08/13/cabeloslisos-ja-sao-minoria-em-comerciais-de-tv.html>. Acesso em: 10/12/2020.

SANTOS, N. Entenda a importância da taxa de recompra para o seu negócio. Listenx, 22 jun. 2020. Disponível em: https://listenx.com.br/blog/taxa-de-recompra/ Acesso em: 08 de maio de 2021.

SOLOMON, M. R. Comportamento do Consumidor: Comprando, Possuindo e Sendo. Bookman, 11 ed. São Paulo, 2016.

STUPP, M. Pesquisa comprova a relevância dos influenciadores digitais no Brasil .21 nov. 2019. Disponível em:<https://criadoresid.com/ibge-influenciadoresdigitais/>. Acesso em: 03 de maio de 2021.

TAVARES, M. C. Gestão de Marcas: construindo marcas de valor. São Paulo: Harbra, 2008.

VALENTE, J. Brasil tem 134 milhões de usuários de internet, aponta pesquisa A maioria acessa a internet pelo celular. Agencia Brasil, Brasília, 26 mai. 2020. 
Disponível em: <https://agenciabrasil.ebc.com.br/geral/noticia/2020-05/brasil-tem134-milhoes-de-usuarios-de-internet-aponta-pesquisa>. Acesso em: 12 de maio de 2021.

VÁSQUEZ, R. P. Comunicação de marca: aportes da publicidade impressa na comunicação da identidade de marca. 2006. 372 p. Tese (Doutorado em Ciências da Comunicação) - Escola de Comunicações e Artes, Universidade Federal de São Paulo.

VIEIRA, K. Black power: instrumento de resistência e cultura. Afreaka, 2021? Disponível em: < http://www.afreaka.com.br/notas/black-power-instrumento-deresistencia-e-cultura/>. Acesso em: 15 de maio de 2021.

VOLPATO, B. Ranking das redes sociais 2020: as mais usadas no Brasil e nomundo, insights e materiais. Resultados digitais, 11 jan. 2021. Disponível em: <gratuitoshttps://resultadosdigitais.com.br/blog/redes-sociais mais-usadas-nobrasil/>. Acesso em: 20 de maio de 2021.

WAGNER, W. Publicidade $\mathrm{x}$ propaganda: saber as diferenças determina o rumo das campanhas. Disponível em: $<$ https://hubcriacao.com.br/2018/11/18/publicidade-x-propaganda-saber-asdiferencas-determina-o-rumo-das-campanhas/>.Acesso em: 12 de maio 2006.

WEBER, M. Brasil é o quarto maior mercado de beleza e cuidados pessoais no mundo. Forbes Brasil. 4 de julho de 2020. Disponível em: $<$ https://forbes.com.br/negocios/2020/07/brasil-e-o-quarto-maior-mercado-debeleza-e-cuidados-pessoais-do-mundo/>. Acesso em: 23 de outubro de 2020. 


\section{Anexo 1}

Roteiro da Pesquisa Qualitativa: Motivação da consumidora da Geração Y e estratégias de comunicação das marcas para cabelos cacheados e crespos.

Olá!

Eu sou aluna de Administração de empresas da Puc Rio e estou fazendo uma pesquisa para o meu trabalho de conclusão de curso sobre as motivações da consumidora da Geração $Y$ e as estratégias de comunicação das marcas para cabelos cacheados e crespos. A primeira parte consistiu em duas perguntas tipo filtro respondidas por você, agora a segunda parte são perguntas abertas.

Desde já, agradeço a sua colaboração!

Primeira parte (perguntas filtro)

1 Quantos anos você tem?

2 Você é consumidora de produtos específicos para cabelos cacheados e crespos?

Segunda parte (perguntas qualitativas)

1. O que te motiva a comprar produtos para cabelos? Comente.

2. O que é um fator primordial para você decidir comprar determinado produto (preço, marca, embalagem, facilidade de encontrar, qualidade, atributos ou benefícios)? Comente

3. Quais são suas fontes de informação ao pesquisar por determinado produto?

4. Por quais motivos você considera tais fontes de informação ao decidir pela compra? 
5. Que tipo de campanha, propaganda ou ação da marca para divulgar de determinado produto te chamou mais atenção ou te motivou a comprar? Comente.

6. Você é ou foi influenciado por celebridades em comercial de Televisão em suas escolhas de produtos para cabelo? Comente.

7. Pensando nas marcas nas redes sociais, qual sua opinião sobre a interatividade delas com as consumidoras? Comente.

8. Quais mídias sociais das marcas você acompanha? Com qual frequência?

9. Por quais motivos você acompanha estas mídias?

10. O que você pensa sobre as marcas utilizarem as influenciadoras digitais para recomendação de produtos? Comente.

11. Com qual frequência você compra produtos após assistir propaganda/recomendação feita por uma influenciadora digital?

12. Sustentabilidade (produtos veganos e "verdes") e diversidade (publicidade com diferentes tipos de mulheres nas campanhas, sem seguir um padrão) são temas em voga na comunicação das marcas, o que você acha dessas pautas? Comente.

13. Você gostaria de ver outros temas na publicidade e ações da marca? Quais? Se sim, por qual motivo?

14. O quanto você se sente representada pelas marcas de cabelos cacheados e crespos? Comente. 